\title{
Electron spin resonance in membrane research: Protein-lipid interactions
}

\author{
Derek Marsh * \\ Max-Planck-Institut für biophysikalische Chemie, Abt. Spektroskopie, Am Fassberg 11, 37070 Göttingen, Germany
}

\section{A R T I C L E I N F O}

Article history:

Accepted 3 July 2008

Available online 29 July 2008

\section{Keywords:}

Spin-label

ESR

EPR

Lipid-protein interactions

Integral proteins

Peripheral proteins

Transmembrane peptides

\begin{abstract}
A B S T R A C T
Different electron spin resonance (ESR) methods are described that allow determination of the stoichiometry and selectivity of interaction of spin-labelled lipids with integral transmembrane peptides or proteins, and also with peripheral surface-binding membrane proteins or peptides. In addition, ESR methods for determining the exchange rates of spin-labelled lipids at the protein-lipid interface are described, as well as methods to detect penetration of surface-binding peptides into the hydrophobic membrane core. Instrumental requirements are considered, and also sample handling, spin-labelling techniques and the synthesis of spin-labelled lipids.
\end{abstract}

(c) 2008 Elsevier Inc. All rights reserved.

\section{Introduction}

Spin-label ESR spectroscopy is a method that is sensitive to the molecular mobility of membrane components and, unlike optical spectroscopy, is applicable to opaque or highly scattering membranous samples. Its principal advantage for studying lipid-protein interactions lies in the fact that the time-scale of sensitivity of conventional ESR spectra from nitroxide spin-labels is optimally matched to the rotational motions of lipids in membranes. This allows C14-position spin-labelled lipids (see Fig. 1) at the intramembranous perimeter of a transmembrane protein to be resolved spectrally from those in the bulk bilayer regions of the membrane because of their difference in rotational mobility [1]. For surfaceinteracting peptides or proteins, the lipid-protein interactions are revealed by generalised perturbations of the anisotropic rotational diffusion of the lipid chains that characterises fluid bilayer membrane assemblies. This is best studied with lipids spin-labelled at the C5-position of the (sn-2) chain. See Refs. [2-17] for reviews.

\section{ESR spectrometer requirements}

Standard $9 \mathrm{GHz}$ frequency (X-band) ESR spectrometers are suitable for spin-label studies. This continuous-wave (CW) type of spectrometer uses field modulation (normally at $100 \mathrm{kHz}$ ) and phase-sensitive detection, which results in the ESR spectra being displayed as the first derivative with respect to the magnetic field scan. The field modulation amplitude should be less than the line-

\footnotetext{
* Fax: +495512011501.

E-mail address: dmarsh@gwdg.de
}

width, i.e., $\leqslant 1.5 \mathrm{G}$ except for the broad lines in the spectra from rotationally immobilised (slow-motion) samples. The spectra are centred in the normal $g=2$ region (at ca. 3250-3400 G), and do not require particularly high resolution, nor wide sweep-widths (normally 100-150 G). Standard microwave cavities may be used but, for samples of limited size, loop-gap resonators [18] or dielectric resonators are advantageous because of higher filling factorsand also for saturation studies where higher microwave $\left(H_{1}\right)$ fields are desirable. In standard applications, the microwave power should be set to avoid appreciable saturation $(\leqslant 10 \mathrm{~mW})$. For saturation transfer ESR studies, moderately saturating microwave powers are used, and, in progressive saturation experiments, the microwave power is stepped systematically. Sample temperature is controlled by thermostatted gas flow, through a double-wall quartz Dewar that inserts into the microwave cavity. Temperature can be measured with a fine-wire thermocouple positioned close to the sample. Care must be taken to avoid microwave heating in power saturation studies. Experimental details and operating procedures can be found in $[19,20]$.

\section{ESR sample cells}

The most useful sample cells for membrane preparations are generally $1-\mathrm{mm}$ i.d. thin glass capillaries, such as those used for standard $50-100 \mu \mathrm{l}$ positive-delivery pipettes. These can be flame-sealed readily. (Glass does have some microwave loss, but seldom gives particularly troublesome background signals. Ideally, ESR-grade quartz capillaries would be used, but these are not essential for routine measurements.) The membrane must be packed in the capillary-after transferring the homogenized 


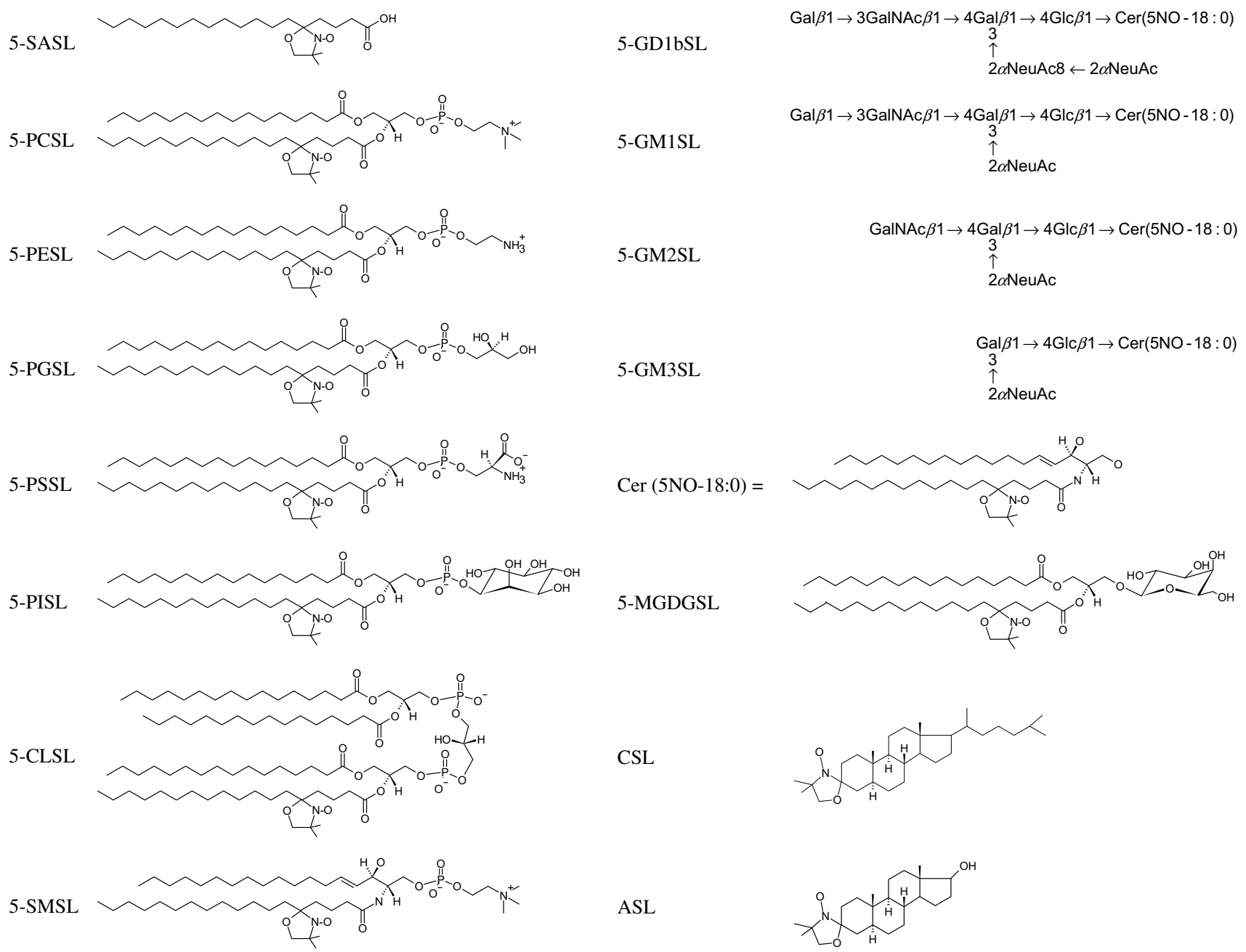

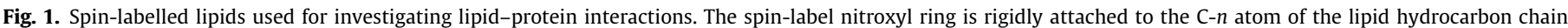

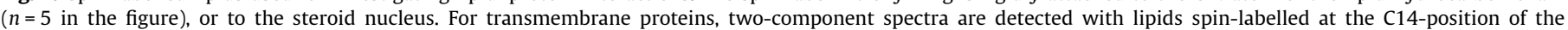

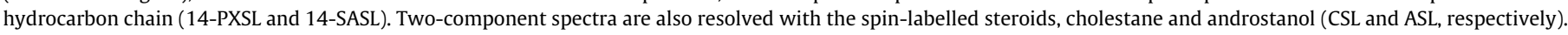

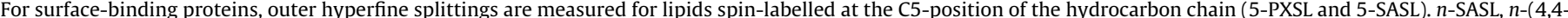

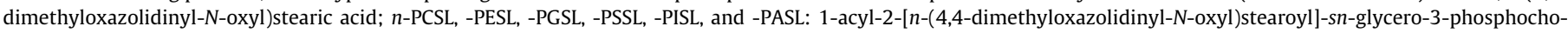

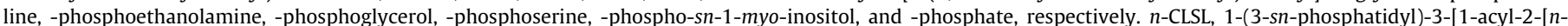

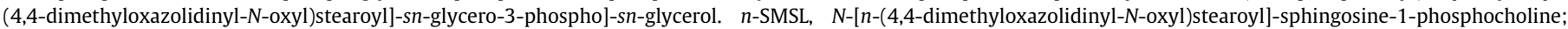

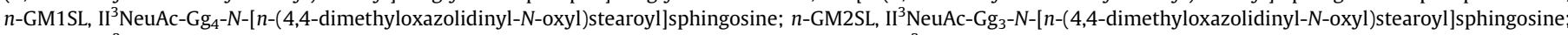

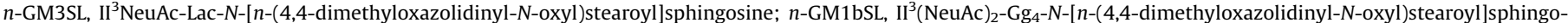

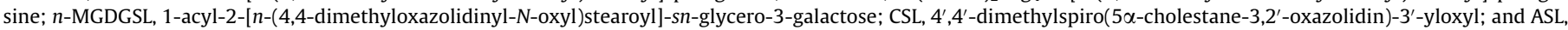
$17 \beta$-hydroxy-4', $4^{\prime}$-dimethylspiro( $5 \alpha$-androstane-3,2'-oxazolidin)-3'-yloxyl.

suspension with a drawn-out Pasteur pipette-by slow-speed centrifugation with a bench-top, or haematocrit, centrifuge. Excess supernatant is then removed-leaving only a small amount to prevent the sample drying out-to minimize the microwave losses associated with liquid water. A final membrane pellet of $5-\mathrm{mm}$ height is ideal. The sealed capillaries are accommodated in a standard 4-mm diameter quartz ESR tube (in the gas-flow Dewar) which contains dry, light silicone oil for thermal stability and a fine-wire thermocouple for temperature measurement. The membrane sample must be centred in the microwave cavity, so that it will experience the maximum microwave and modulation magnetic fields.

Special quartz ESR flat cells with a $0.3-\mathrm{mm}$ internal spacing are available for optimum sensitivity with aqueous solutions, but these are less suitable for particulate samples and are difficult to thermostat. Solutions in apolar (i.e., 'non-lossy') solvents can be examined in standard 4-mm quartz ESR tubes.

\section{ESR sample requirements}

Typically $0.5 \mathrm{mg}$ of sample is suitable; smaller amounts are possible, especially if loop-gap resonators together with a low-gain microwave preamplifier are used. The membranes are doped with spin-labelled lipids at a level of $0.5-1 \mathrm{~mol} \%$ spin-label with respect to total lipid in the sample. For samples prepared by hydrating lipid-peptide mixtures dried from organic solvent, the lipid spin-label can be added to the organic solvent. For membrane samples, and often for samples reconstituted by dialysis, the spin-labelled lipid must be added exogenously to the aqueous membrane dispersion as a small volume ( $c a .1 \mu \mathrm{l})$ of concentrated solution in ethanol (with vortexing). For spin-labelled phospholipids, the sample must then be freed from unincorporated spin-label (which can form its own vesicles spontaneously) by repeated centrifugation and washing. Single-chain spin-labelled lipids, e.g. fatty acids, establish a partition equilibrium and therefore the samples require 
only to be concentrated by a single centrifugation after labelling; the aqueous signal is minimised by removing excess supernatant.

\section{Synthesis of spin-labelled fatty acids, phospholipids and glycolipids}

Chemical structures of the DOXYL (4,4-dimethyloxazolidine- $N$ oxyl) spin-labelled lipids that are used for studying protein-lipid interactions are presented in Fig. 1, which also defines abbreviations. For convenience of illustration, the C5-position isomer of the lipid chain is presented in Fig. 1; for transmembrane proteins, the C14-position isomer is normally used. Table 1 lists the corresponding molecular weights.

Scheme 1 shows the steps in the reaction sequence for synthesis of the keto-acid methyl esters that are the starting products for fatty acids spin-labelled with the DOXYL moiety at specific C-atom positions in the hydrocarbon chain (for stearic acid: $n$-(4,4-dimethyloxazolidine- $N$-oxyl)stearic acid; $n$-SASL-see Fig. 1 ). Depending on availability of starting materials, not all steps are necessarily required. For instance, the sequence may start at the di- or monomethyl ester of the dicarboxylic acid, or at the Grignard reaction [21], and for 12-SASL the methyl 12-keto stearate is directly available derived from a natural product [22]. Protocols for preparation of methyl-14-ketostearate are given in Ref. [23].

Table 1

Molecular weights of spin-labelled lipids

\begin{tabular}{llc}
\hline Label & Formula & Molecular weight \\
\hline DOXYL (additional) & $\mathrm{C}_{4} \mathrm{H}_{6} \mathrm{NO}_{2}$ & 100.1 \\
$n$-SASL & $\mathrm{C}_{22} \mathrm{H}_{42} \mathrm{NO}_{4}$ & 384.6 \\
$n$-PCSL $\cdot \mathrm{H}_{2} \mathrm{O}$ & $\mathrm{C}_{46} \mathrm{H}_{94} \mathrm{~N}_{2} \mathrm{O}_{11} \mathrm{P}$ & 882.2 \\
$n$-PESL & $\mathrm{C}_{43} \mathrm{H}_{84} \mathrm{~N}_{2} \mathrm{O}_{10} \mathrm{P}$ & 820.1 \\
$n$-PGSL & $\mathrm{C}_{44} \mathrm{H}_{85} \mathrm{NO}_{12} \mathrm{P}$ & 851.1 \\
$n$-PASL & $\mathrm{C}_{41} \mathrm{H}_{79} \mathrm{NO}_{10} \mathrm{P}$ & 777.0 \\
$n$-PISL & $\mathrm{C}_{47} \mathrm{H}_{89} \mathrm{NO}_{15} \mathrm{P}$ & 939.2 \\
$n$-CLSL & $\mathrm{C}_{79} \mathrm{H}_{152} \mathrm{NO}_{19} \mathrm{P}_{2}$ & 1482.0 \\
$n$-SMSL & $\mathrm{C}_{45} \mathrm{H}_{90} \mathrm{~N}_{3} \mathrm{O}_{8} \mathrm{P}$ & 832.2 \\
$n$-GD1bSL & $\mathrm{C}_{88} \mathrm{H}_{154} \mathrm{~N}_{5} \mathrm{O}_{40}$ & 1954.2 \\
$n-G M 1 S L$ & $\mathrm{C}_{77} \mathrm{H}_{137} \mathrm{~N}_{4} \mathrm{O}_{33}$ & 1646.9 \\
$n-G M 2 S L$ & $\mathrm{C}_{71} \mathrm{H}_{127} \mathrm{~N}_{4} \mathrm{O}_{28}$ & 1484.8 \\
$n-$ GM3SL & $\mathrm{C}_{63} \mathrm{H}_{114} \mathrm{~N}_{3} \mathrm{O}_{23}$ & 1281.6 \\
$n$-MGDGSL & $\mathrm{C}_{47} \mathrm{H}_{88} \mathrm{NO}_{12}$ & 859.2 \\
CSL & $\mathrm{C}_{31} \mathrm{H}_{53} \mathrm{NO}_{2}$ & 471.8 \\
ASL & $\mathrm{C}_{23} \mathrm{H}_{38} \mathrm{NO}_{3}$ & 376.6 \\
\hline
\end{tabular}

The spin-labelled chain is assumed to be stearoyl (C18:0) and all other acyl chains palmitoyl (C16:0), and the sphingoid base is taken to be sphing-4-enine (d18:1).
Scheme 2 shows the reaction sequence for synthesis of DOXYL spin-labels from the corresponding keto compound by condensation with 2-amino-isopropanol and subsequent oxidation of the secondary amine function to yield the nitroxide [24]. This reaction scheme may be applied not only to the keto acid methyl esters yielding the $n$-SASL spin-labels, but also to the keto steroids, cholestane-3-one and 4-androstane-17-hydroxy-3-one, to yield the CSL ( $4^{\prime}, 4^{\prime}$-dimethylspiro( $5 \alpha$-cholestane-3, $2^{\prime}$-oxazolidin)- $3^{\prime}$-yloxyl) and ASL (17 $\beta$-hydroxy- $4^{\prime}, 4^{\prime}$-dimethylspiro(5 $\alpha$-androstane-3,2'oxazolidin)-3'-yloxyl) spin-labels, respectively. A protocol for preparation of 14-SASL is given in Ref. [23].

Minimal-perturbation spin-labelled fatty acids, in which the nitroxide ring is incorporated as an integral part of the hydrocarbon chain, are synthesised as described in $[25,26]$. These fatty acids are 2,4-, 2,5- and 3,2-substituents of 2,2,5,5-tetramethylpyrrolidine- $N$-oxyl [3-(2',4')FASL, 2,5,5-trimethyl-4-undecyl-2-(3carboxypropyl)pyrrolidine- $N$-oxyl; 4-(2',4')FASL, 2,5,5-trimethyl4-decyl-2-(4-carboxybutyl)pyrrolidine- $N$-oxyl; 5-(2',4')FASL, 2,5,5trimethyl-4-nonyl-2-(5-carboxypentyl)pyrrolidine- $N$-oxyl; 4-(2, $\left.5^{\prime}\right)$ FASL, 2,5-dimethyl-5-decyl-2-(4-carboxybutyl)pyrrolidine- $N$-oxyl; 8-(3',2')FASL, 2,5,5-trimethyl-2-pentyl-3-(8-carboxyoctyl)pyrrolidine- $N$-oxyl] [27]. Reference ESR data for these special spinlabelled fatty acids in lipid-protein systems are given in [28].

Scheme 3 shows the reaction scheme for acylation of lysophosphatidylcholine with the spin-labelled fatty acid imidazole, yielding the spin-labelled phosphatidylcholine, $n$-PCSL [29]. Acyl chain migration may be minimised by using an excess of spin-labelled fatty acid and by limiting the reaction time. Non-reacted fatty acid may be recovered to conserve spin-labelled compound. A protocol for preparation of $n$-PCSL spin-labelled phosphatidylcholines from spin-labelled $n$-SASL stearic acids is given in Ref. [23]. Acylation with the fatty acid anhydride, catalysed by 4-pyrrolidinopyridine, requires short reaction times (with a 5 -fold excess of fatty acid) and minimises acyl chain migration [30]; this method can also be used in synthesis of spin-labelled phospholipids [31]. For synthesis of spin-labelled phosphatidylinositol ( $n$-PISL; [32]), the free hydroxyl groups of phosphatidylinositol must be acetylated prior to treatment with phospholipase $A_{2}$, as described in Ref. [33] for synthesis of a fluorescent analogue. After acylation of the resulting pentaacetyllysophosphatidylinositol with spin-labelled fatty acid, the protecting acetyl groups are removed by hydrazinolysis. The protocol for preparation of 14-PISL is given in Ref. [31].

Scheme 4 shows the method for producing different spinlabelled phospholipid species from transphosphatidylation
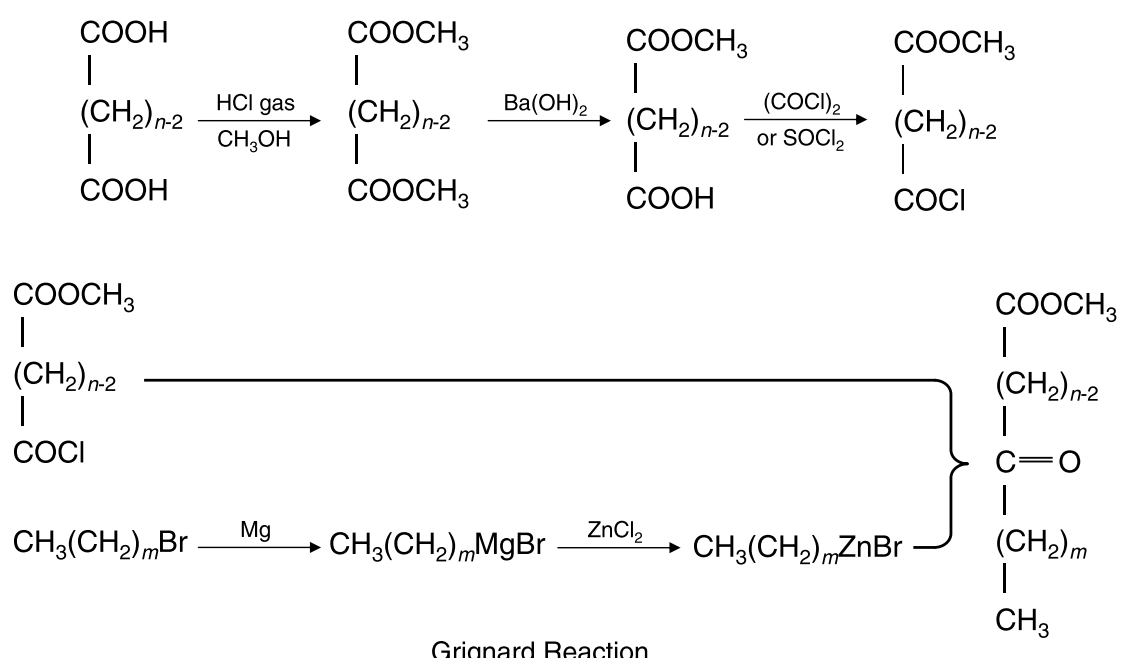

Scheme 1. 
$\stackrel{\mathrm{O}}{\stackrel{\mathrm{II}}{\mathrm{C}} \mathrm{R}_{1}}+\underset{\mathrm{R}_{2}}{\stackrel{\mathrm{CH} \mathrm{NH}_{2}}{\mathrm{CH}_{3}}}+\mathrm{H}_{3}$<smiles>[R]C1([R])OCC(C)(C)N1O</smiles>

$$
\mathrm{R}_{1}=\mathrm{CH}_{3}\left(\mathrm{CH}_{2}\right)_{\mathrm{m}}-
$$$$
\mathrm{R}_{2}=-\left(\mathrm{CH}_{2}\right)_{n-2} \text { COOEster }(\text { Ester }=\text { Me or Et })
$$<smiles>[R]C1([R])NC(C)(C)CO1</smiles>
$40^{\circ} \mathrm{C} / 1 \mathrm{~h}$

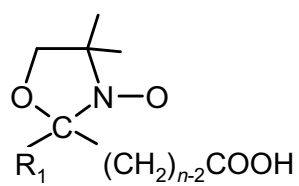

$n$-SASL

Scheme 2.

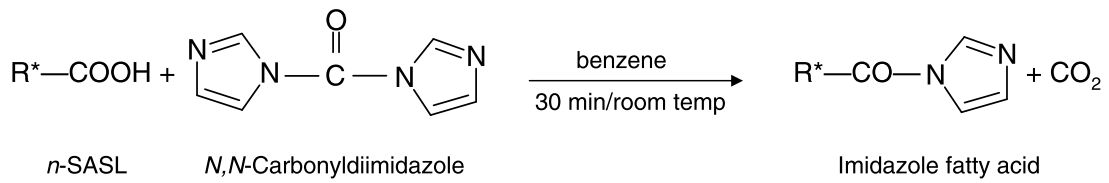<smiles>[R]C(=O)OCC(O)COP(=O)([O-])OCCN(C)C(=O)OC(C)=O</smiles>

lysophosphatidylcholine

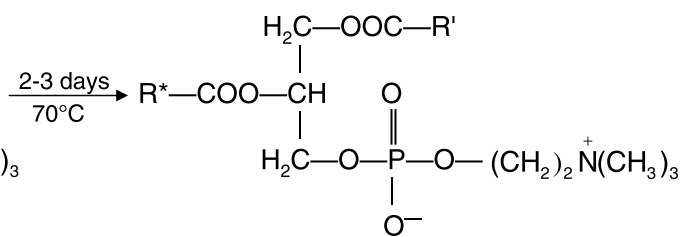

n-PCSL

$$
\begin{aligned}
& \mathrm{R}^{\prime}=\mathrm{CH}_{3}\left(\mathrm{CH}_{2}\right)_{14}-\text {, palmitic acid } \\
& \mathrm{R}^{\star}=\mathrm{CH}_{3}\left(\mathrm{CH}_{2}\right)_{m}-\left(\mathrm{CH}_{2}\right)_{n-2}-, n \text {-SASL, stearic acid spin label }(m=17-n)
\end{aligned}
$$

Scheme 3.

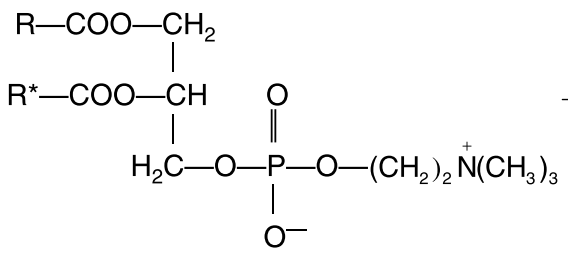

n-PCSL<smiles>[X]OP(=O)([O-])OCC(COC([R])=O)OC(=O)[R]OC(=O)O</smiles>

n-PXSL

$$
\begin{aligned}
\mathrm{R} & =\text { acyl chain } \\
\mathrm{R}^{\star} & =\text { spin-labeled acyl chain, } n \text {-SASL } \\
\mathrm{X} & =\mathrm{H} \rightarrow \mathrm{PASL} \\
& =\left(\mathrm{CH}_{2}\right)_{2} \mathrm{NH}_{2} \rightarrow \mathrm{PESL} \\
& =\mathrm{CH}_{2} \mathrm{CH}(\mathrm{OH}) \mathrm{CH}_{2} \mathrm{OH} \rightarrow \mathrm{PGSL} \\
& =\mathrm{CH}_{2} \mathrm{CH}\left(\mathrm{NH}_{2}\right) \mathrm{COOH} \rightarrow \mathrm{PSSL}
\end{aligned}
$$


mediated by phospholipase D [34]. Headgroup exchange is accomplished catalytically in the presence of a large excess of the appropriate alcohol. Care must be taken to exclude methanol or ethanol because these very efficiently produce the corresponding methyl and ethyl phosphatidic acids. Protocols for preparation of $n$-PGSL, $n$-PASL, $n$-PESL and $n$-PSSL spin-labelled phospholipids from $n$ PCSL are given in Ref. [23].

Scheme 5 shows the method for producing the spin-labelled tetraacyl phospholipid diphosphatidylglycerol (cardiolipin, $n$-CLSL) by acylation of monolysocardiolipin according to Cable et al. [35]. Prolonged action of phospholipase $\mathrm{A}_{2}$ additionally produces dilysocardiolipin, which may be acylated to produce spin-labelled monolysocardiolipin (14-lysoCLSL; [36,37]).

Synthesis of spin-labelled sphingomyelins ( $n$-SMSL; [38]) may be accomplished by the coupling reaction of the $\mathrm{N}$-succinimidyl ester [39] of spin-labelled stearic acid ( $n$-SASL) with sphingosine-1phosphocholine [40].

Spin-labelled analogues of sialoglycosphingolipids (gangliosides; 14-GM1SL, 14-GM2SL, 14-GM3SL and 14-GD1bSL) may be synthesized by selective $N$-acylation of the corresponding lysogangliosides with the spin-labelled $N$-succinimidyl ester of 14-SASL, as described in [41]. Reference ESR data for spin-labelled gangliosides in lipid-protein systems are given in [31] and [42].

Spin-labelled glycoglycerolipids (e.g., monogalactosyldiacylglycerol, 12-MGDGSL) can be synthesised as described by Nishida and Yamada [43]. This procedure yields 30\% chain migration, which is much greater than that for phospholipid spin-labels. Reference ESR data for spin-labelled 12-MGDGSL in lipid-protein systems are given in [44-46].

Spin-labelled local anaesthetics (analogues of benzocaine, procaine, tetracaine, procainamide and procaine thioester; [47]) are synthesised as described in [48]. These hydrophobic anaesthetics localise to the lipid-protein interface in membranes enriched with the nicotinic acetylcholine receptor [49].
Spin-labelled analogues of the 5-(5,6-dichloro-2-indolyl)-2methoxy-2,4-pentadienamide family of specific inhibitors of the vacuolar ATPase (INDOL6 and INDOL5) are synthesised as described in Refs. [50,51]. These hydrophobic spin-labelled inhibitors likewise localise to the lipid-protein interface in membranes containing assemblies of the $16-\mathrm{kDa}$ proteolipid subunit $c$ of the V-ATPase [52].

\section{Lipid-protein interactions with transmembrane proteins: two-component spectra}

Ideally, the spin-label is attached at the C14-atom of stearic acid (14-SASL), which is acylated as the $s n-2$ chain in the case of phospholipids. The need for this position of labelling is to obtain a narrow (i.e., mobile) spectrum from the fluid lipid regions of the membrane, in order to resolve the motionally restricted lipids that are interacting directly with the protein and appear in the outer wings of the spectrum (see, e.g., Refs. [53-56] for illustrations of the spectral lineshapes from spin-labelled lipid chains). The temperature at which the spectrum is recorded is adjusted to optimize the resolution of these two components, and this depends on the position of spin-labelling and on the fluidity of the particular membrane system. Typical two-component spectra are shown in Fig. 2, where they are compared with the single-component spectra from membranes of the lipids alone.

Of the commercially available stearic-acid derivatives (Sigma, St. Louis, MO), that labelled on the C16-atom (16-SASL) is most suitable (cf. Fig. 2). Phosphatidylcholine spin-labelled on the C12-, C14- or C16-atom of the sn-2 chain (12-, 14- or 16-PCSL) is available from Avanti Polar Lipids (Alabaster, AL).

\section{Spectral subtraction and addition}

The two components are quantified by computer subtraction or addition of the digitized spectra (see Fig. 3). The protocol is given in<smiles>[R]C(=O)OCC(COP(=O)(OCC(C)O)OC(COC([R])=O)COP(=O)([O-])OC)OC([R])=O</smiles>

Imidazole fatty acid (see Scheme 3)

$\mathrm{R}_{1}, \mathrm{R}_{2}, \mathrm{R}_{3}, \mathrm{R}_{4}=$ acyl chains; $\mathrm{R}^{\star}=$ fatty acid spin label, $n$-SASL

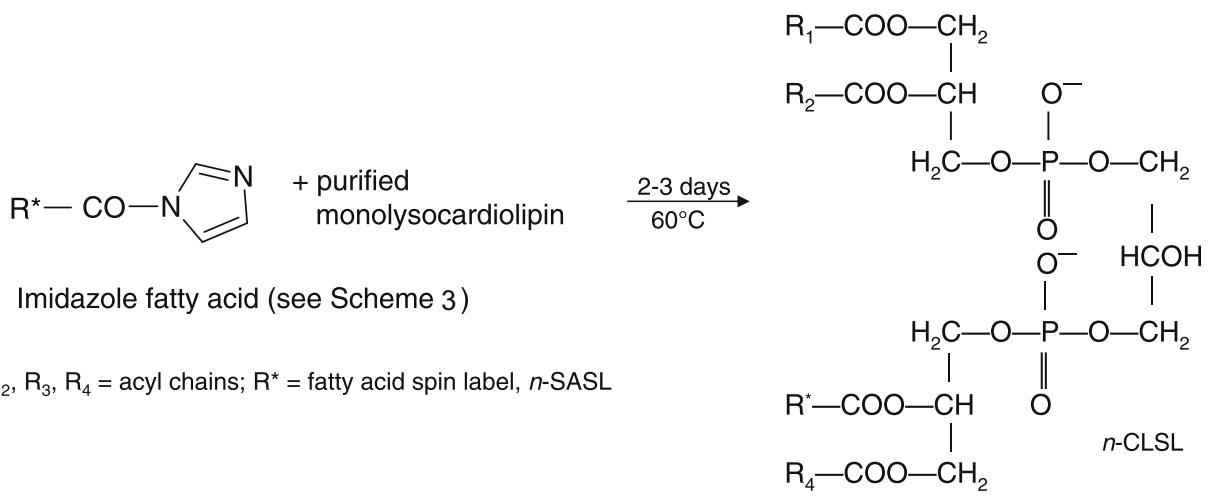

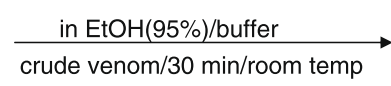<smiles>[R]C(=O)OCC(O)COP(=O)([O-])OCC(COC([R])=O)OP(=O)([O-])OCC(C)OC([R])=O</smiles>
cardiolipin 


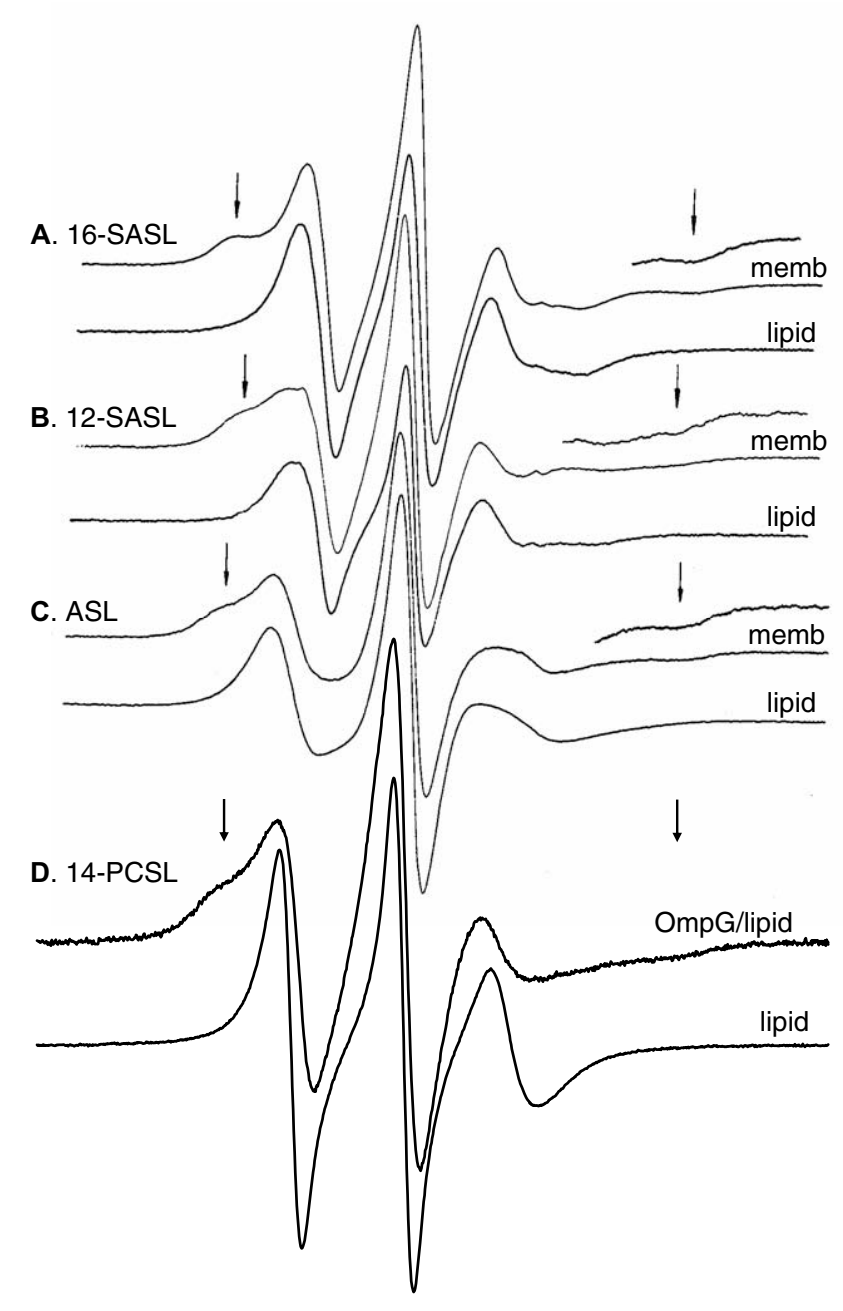

Fig. 2. Two-component ESR spectra of spin-labelled lipids in lipid/protein membranes and single-component spectra in lipid bilayer membranes. Arrows indicate the spectral component from motionally restricted lipids. Stearic acid: 16-SASL at $-4{ }^{\circ} \mathrm{C}(\mathrm{A})$ and 12 -SASL at $34^{\circ} \mathrm{C}(\mathrm{B})$, and androstanol at $14^{\circ} \mathrm{C}(\mathrm{C})$ in nicotinic acetylcholine receptor-rich membranes from Torpedo marmorata. Data from Ref [161]. (D) phosphatidylcholine (14-PCSL) in $\operatorname{diC}_{14: 0} \mathrm{PC}$ membranes containing Escherichia coli outer membrane protein OmpG $(1: 32 \mathrm{~mol} / \mathrm{mol})$ at $30^{\circ} \mathrm{C}$. Data from Ref. [78]. Total scan width $=100 \mathrm{G}$.

Ref. [19]. The single-component spectrum corresponding to the fluid lipid environment which is required for subtraction is obtained from a dispersion of the extracted membrane lipids (see [57]), or from a lipid dispersion without peptide or protein in the case of reconstituted systems. These spectra are recorded at closely spaced $\left(1^{\circ}\right)$ temperature intervals, in order to have a library from which to choose the one that best matches the fluid component in the two-component membrane spectrum. The single-component spectrum corresponding to the protein-interacting environment which is required for the complementary subtraction is obtained from sonicated, small unilamellar vesicles of dimyristoyl phosphatidylcholine $\left(\mathrm{diC}_{14: 0} \mathrm{PC}\right)$ in the gel phase (i.e., below $20^{\circ} \mathrm{C}$ ). Again a spectral library is recorded at closely spaced temperature intervals (from $\mathrm{ca} .0^{\circ} \mathrm{C}$ or lower). For protein/diC $\mathrm{di}_{14: 0} \mathrm{PC}$ and similar mixtures, spectra recorded from sonicated $\mathrm{diC}_{14: 0} \mathrm{PC}$ above the phase transition may constitute a better library for matching the fluid component than do those from unsonicated $\operatorname{diC}_{14: 0} \mathrm{PC}$. The advantage of the sonicated system is that it exhibits a wider range of linewidths. Subtraction endpoints are assessed by comparison of the difference spectrum with the complementary single-component spectrum. For optimising the endpoint in subtracting the motionally restricted component, the difference spectrum should be displayed with vertical expansion for sensitive comparison with the complementary reference in the outer wings of the fluid component. The best-matching single components are chosen by an iterative procedure.

The relative proportions of the two components are then obtained from the fraction, $f$, of the double-integrated intensity (ESR spectra are first-derivative displays) of the single-component spectrum, relative to the two-component spectrum, that has to be subtracted. Ideally the two subtraction factors from the complementary subtractions should add up to one, i.e., are $f$ and (1- $f$ ). If they are close, the two values should be averaged. If the fluid component has narrow lines and dominates the two-component spectrum, it may prove difficult to match exactly and only the complementary subtraction of the motionally restricted component may be feasible. In these cases, analysis by spectral addition (see Fig. 3a, right panel) may be preferable. The best match of the two added components can be established by least-squares minimisation of the differences from the original composite experimental spectrum [58].

Table 2 lists several lipid-protein or lipid-peptide systems that give rise to two-component lipid ESR spectra and have been quantified in this way. The total lipid/protein ratios are given, together with the fractional populations of motionally restricted lipid that are resolved. These serve as valuable reference data, particularly as a catalogue of lineshapes for two-component spectra where both the relative proportions and mobilities of the two components vary from system to system.

\section{Stoichiometry and selectivity of lipid interactions with transmembrane proteins}

The fractional population, $f$, of motionally restricted lipids yields information on both the stoichiometry and the selectivity of the lipid-protein interaction. The total phospholipid/protein molar ratio, $N_{t}$, of the sample must be determined by chemical analysis, i.e., protein [80] and phosphate [81] assays.

The number of lipid association sites on the protein is obtained from the equation for equilibrium lipid exchange association with the protein, which is given by $[82,83]$ :

$\left(\frac{1-f}{f}\right)=\frac{1}{K_{r}}\left(\frac{N_{t}}{N_{b}}-1\right)$

for probe concentrations $\left(<<N_{t}\right)$ of spin-labelled lipid, where $K_{r}$ is the association constant of the spin-labelled lipid probe with the protein, relative to that of the unlabelled background host lipid. Several studies have shown that $K_{r} \approx 1$ for a spin-labelled analogue of the background lipid, i.e., that spin-labelling of the lipid does not disturb the thermodynamics of lipid-protein association. The number, $N_{b}$, of lipid association sites at the intramembranous surface of the protein may therefore be determined directly by using a spinlabelled phospholipid (usually phosphatidylcholine, 14-PCSL) for which $K_{r, o}=1$. The stoichiometry is then given simply by:

$N_{b}=f_{o} \times N_{t}$

where $f_{o}$ is the fractional motionally restricted population of the non-selective spin-labelled lipid.

Specificities of interaction can be determined by measuring $f$ for different spin-labelled lipid species in membranes of fixed lipid/ protein ratio, $N_{t}$. The relative association constant is then given from Eq. (1) by:

$K_{r}=f\left(1-f_{o}\right) /\left[f_{o}(1-f)\right]$

using the non-selective spin-label (for which $K_{r, o}=1$ ) as reference. Table 3 gives essential reference data for the interaction of a range 


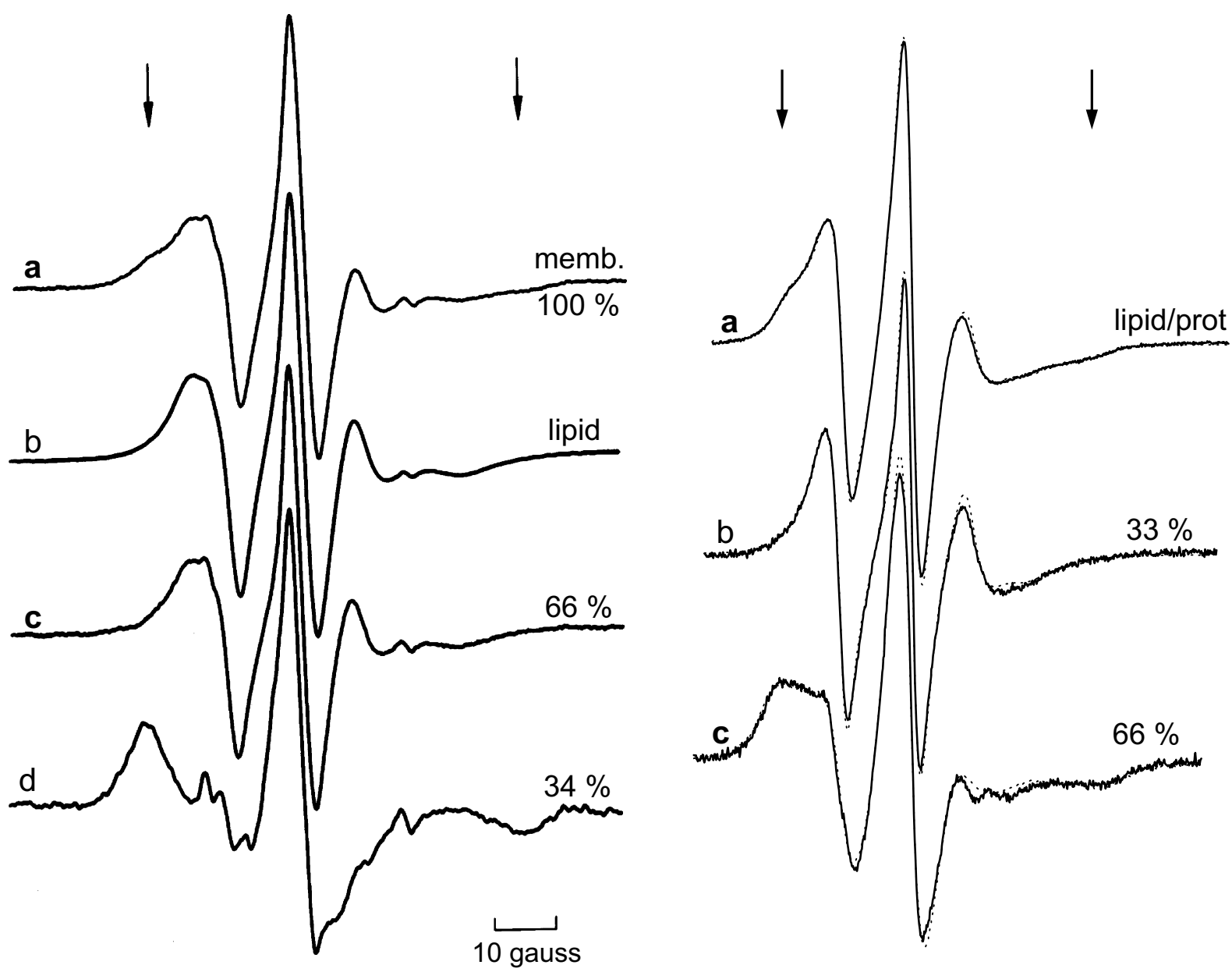

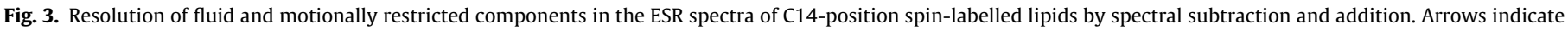

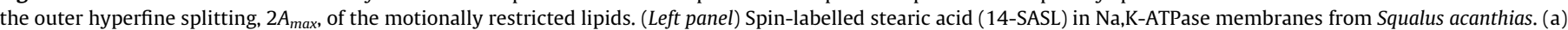

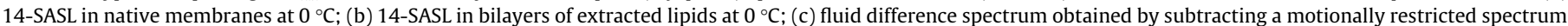

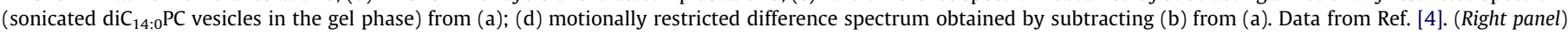

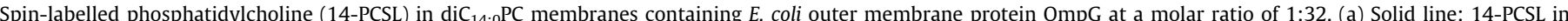

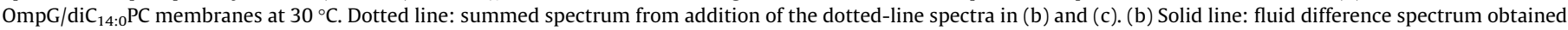

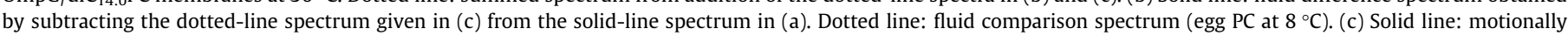

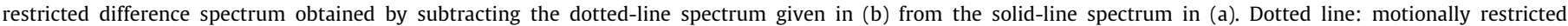

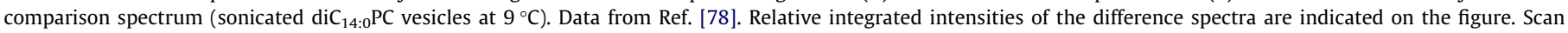
width $=100 \mathrm{G}$

of spin-labelled lipid species, 14-PXSL, with different transmembrane proteins and peptides.

If the lipid-protein ratio can be varied, either by reconstitution or by progressive delipidation of the membrane, the dependence on $N_{t}$ can be fitted to Eq. (1) to yield values of both $N_{b}$ and $K_{r}$ simultaneously. The value of $N_{b}$ is given (quite generally) by the intercept on the $N_{t}$ axis in a plot of $(1-f) / f$ against $N_{t}$, and the relative association constant is given by the intercept $-1 / K_{r}$ on the $(1-f) / f$ axis (see lower panel of Fig. 4). Such lipid/protein titrations require that $N_{t}>N_{b}$, in order to avoid non-specific protein-protein aggregation.

\section{Interpretation of lipid stoichiometries}

The stoichiometry of motionally restricted lipids is a direct measure of the size of the intramembranous perimeter of the protein or peptide assembly. This in turn is determined by the arrangement of the transmembrane segments and also by the degree of protein oligomerisation. For a helical sandwich or for a regular polygonal assembly of transmembrane helices, the lipid/ protein stoichiometry is given by $[90,91]$ :
$N_{b}=\pi\left(D_{\alpha} / d_{c h}+1\right)+n_{\alpha} D_{\alpha} / d_{c h}$

where $n_{\alpha}$ is the number of transmembrane helices in the assembly, $D_{\alpha}=1.0 \mathrm{~nm}$ is the diameter of an $\alpha$-helix, and $d_{c h}=0.48 \mathrm{~nm}$ is the diameter of a lipid chain. Note that this value of $D_{\alpha}$ is slightly larger than the interhelical separation at the point of closest packing, which is $\sim 0.85 \pm 0.05 \mathrm{~nm}$ for transmembrane helices [92], and therefore allows to a certain extent for helix splay ( $\sim 0$ to $\pm 20^{\circ}$; [92]) and tilt. For multilayer sandwiches, Eq. (4) is valid for $1<n_{\alpha}<7$, but for $n_{\alpha} \geqslant 7$ centred hexagonal arrangements are possible, in which one of the helices blocks the pore. In this latter case, $n_{\alpha}$ is replaced by $\left(n_{\alpha}-1\right)$, etc.

The predictions of Eq. (4) have been compared both with ESR results from lipid spin-labels, and with 3-D crystal structures of membrane proteins by using molecular mechanics [93]. For relatively small proteins ( $n_{\alpha} \approx 7-12$ ), Eq. (4) predicts stoichiometries that correspond reasonably well with the ESR results and those of modelbuilding (see Table 4). Considerable deviations are found, however, for much larger proteins with more complex internal structure.

Transmembrane $\alpha$-helical assemblies that are less compact than a regular helical sandwich have larger lipid stoichiometries, 
Table 2

Reference data: Fraction, $f_{o}$, of motionally restricted spin-labelled reference lipid (e.g., 14-PCSL) associated with different transmembrane proteins or peptides, where $N_{t}$ is the total lipid/protein ratio

\begin{tabular}{|c|c|c|c|}
\hline Protein & $N_{t}(\mathrm{~mol} / \mathrm{mol})$ & $f_{o}$ & Ref. \\
\hline \multirow[t]{2}{*}{ Cytochrome $c$ oxidase } & $100-350$ & $0.2-0.5$ & [59] \\
\hline & $80-200$ & $0.3-0.7$ & [60] \\
\hline Nicotinic acetylcholine receptor & 360 & 0.12 & [31] \\
\hline Na,K-ATPase, shark & 300 & 0.22 & {$[61,62]$} \\
\hline \multirow[t]{2}{*}{ Rhodopsin, bovine } & 65 & 0.37 & {$[63,64]$} \\
\hline & $40-100$ & $0.2-0.55$ & {$[65,66]$} \\
\hline Rhodopsin, frog & 61 & 0.36 & [67] \\
\hline ADP-ADP carrier & $105-225$ & $0.25-0.5$ & [68] \\
\hline Myelin proteolipid (PLP) & $15-60$ & $0.16-0.5$ & [69] \\
\hline 16-kDa proteolipid & 18 & 0.3 & [70] \\
\hline V-ATPase TM4 peptide ${ }^{a}$ & 12 & 0.3 & [58] \\
\hline Phospholamban (PLB)- $\mathrm{A}^{36,41,46}$ & $20-50$ & $0.15-0.35$ & [71] \\
\hline PLB- $\Delta^{1-25} A^{36,41,46}$ & $10-30$ & $0.15-0.4$ & [71] \\
\hline Gramicidin A & $5-15$ & $0.25-0.7$ & [72] \\
\hline M13 phage coat protein ${ }^{\mathrm{b}}$ & $6.5-16.5$ & $0.3-0.75$ & [73] \\
\hline M13 phage coat protein ${ }^{c}$ & $5-23$ & $0.25-0.8$ & [74] \\
\hline K27, K-channel peptide ${ }^{d}$ & $8-12$ & $0.2-0.35$ & [75] \\
\hline $\mathrm{K} 27-\Delta^{2}$ & $4.5-8$ & $0.35-0.6$ & [76] \\
\hline OmpA & $10-40$ & $0.25-0.9$ & [77] \\
\hline OmpG & $20-45$ & $0.4-0.9$ & [78] \\
\hline FomA & $20-60$ & $0.4-0.9$ & [79] \\
\hline FhuA & $40-80$ & $0.4-0.8$ & [77] \\
\hline
\end{tabular}

a Sequence: RLFVGMILILIFAEVLGLYGLIVALLLN.

b $\alpha$-helical form.

c $\beta$-sheet form.

d Sequence: KLEALYILMVLGFFGFFTLGIMLSYIR

corresponding to their relatively larger intramembranous perimeter. For a linear array of helices, for example, instead of Eq. (4), one finds [91]:
$N_{b}=\pi\left(D_{\alpha} / d_{c h}+1\right)+2\left(n_{\alpha}-1\right) D_{\alpha} / d_{c h}$

which is valid also for $n_{\alpha}=1$. In the latter case of a single bitopic transmembrane helix, the number of perimeter lipids is predicted to be $N_{b} \approx 10$. Note, however, that a single transmembrane helix does not necessarily present a sufficiently extensive intramembranous surface to produce a motionally restricted spin-label component. It does in the case of the L37A mutant of phospholambam (which does not oligomerise) [104], but counter examples include the hydrophobic lung surfactant protein SPC [105], alamethicin [106], and the synthetic Leu-Ala WALP and KALP peptides $[107,108]$.

The stoichiometry per monomer is reduced in oligomeric proteins, because lipids are excluded from the monomer-monomer interfaces within the oligomer. Eq. (4) or (5) also applies approximately to protein oligomers, if the monomers are roughly circular in cross-section and are packed in a manner similar to that assumed above for $\alpha$-helices. Then $D$ is the diameter of the protein monomer and $n$ is the aggregation number. If the oligomer packing is tighter than this and preserves the helical sandwich motif throughout the oligomer, the number of perimeter lipids per protein monomer is given from Eq. (4) by:

$N_{b}^{(1)}=\left(\pi / n_{\text {agg }}\right)\left(D_{\alpha} / d_{c h}+1\right)+n_{\alpha} D_{\alpha} / d_{c h}$

where $n_{\text {agg }}$ is the number of monomers per oligomer. This latter equation makes reasonable predictions for hexameric assemblies of the myelin proteolipid protein [69] and of the 16-kDa proteolipid V-ATPase subunit $c$ [70] (see Table 4).

For a $\beta$-sheet or $\beta$-barrel transmembrane protein, the number of lipids that can be accommodated at the intramembranous surface of the $\beta$-sheet is given approximately by [91]:

Table 3

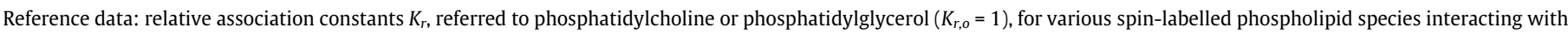
different transmembrane proteins or peptides

\begin{tabular}{|c|c|c|c|c|c|c|c|c|}
\hline Protein & $\mathrm{CL}^{\mathrm{a}}$ & PA & SA & PS & PG & PE & PC & Ref. \\
\hline PLP & - & 10.4 & 6.5 & 2.2 & 1.8 & - & 1.0 & [84] \\
\hline DM-20 & - & 2.3 & 2.0 & 1.1 & 1.0 & & 1.0 & [84] \\
\hline \multirow[t]{2}{*}{ Myelin proteolipid ${ }^{\mathrm{b}}$} & $1.5^{\mathrm{c}}$ & $2.9^{c}$ & $7.0^{\mathrm{c}}$ & $1.4^{\mathrm{c}}$ & $1.1^{\mathrm{c}}$ & $0.5^{\mathrm{c}}$ & 1.0 & [69] \\
\hline & $3.0^{\mathrm{d}}$ & $2.4^{\mathrm{d}}$ & $2.9^{d}$ & $1.4^{\mathrm{d}}$ & $2.0^{\mathrm{d}}$ & $1.7^{\mathrm{d}}$ & 1.0 & [85] \\
\hline Na,K-ATPase & 3.8 & 1.5 & 1.7 & 1.7 & 0.9 & 0.9 & 1.0 & [61] \\
\hline $\mathrm{Na}, \mathrm{K}-\mathrm{ATPase}$-trypsinised & - & - & $1.5,2.8^{\mathrm{e}}$ & 1.9 & - & - & 1.0 & [86] \\
\hline Cytochrome $c$ oxidase & 5.4 & 1.9 & - & 1.0 & 1.0 & 1.0 & 1.0 & [87] \\
\hline ADP-ATP-carrier & 3.8 & 4.3 & 4.1 & 2.4 & 0.8 & - & 1.0 & [68] \\
\hline Nicotinic acetylcholine receptor & 5.1 & - & 4.9 & 2.7 & 1.7 & 0.5 & 1.0 & [31] \\
\hline \multirow[t]{2}{*}{ M13 phage coat protein } & - & $1.6^{\mathrm{g}}$ & $1.2^{\mathrm{g}}$ & $1.2^{\mathrm{g}}$ & $1.1^{\mathrm{g}}$ & $1.0^{\mathrm{g}}$ & 1.0 & [73] \\
\hline & $4.2^{\mathrm{f}}$ & $4.2^{\mathrm{f}}$ & $2.3^{\mathrm{f}}$ & $2.1^{\mathrm{f}}$ & $1.6^{\mathrm{f}}$ & $0.9^{\mathrm{f}}$ & 1.0 & [88] \\
\hline 16-kDa proteolipid & - & - & 2.4 & 1.5 & 1.4 & - & 1.0 & {$[70]$} \\
\hline K27, K-channel peptide ${ }^{\mathrm{h}}$ & - & 3.3 & 2.0 & 2.0 & 1.1 & - & 1.1 & [75] \\
\hline$K 27-\Delta^{2}$ & - & 4.3 & 4.3 & 2.5 & 1.0 & - & 1.0 & [76] \\
\hline Phospholamban- $\mathrm{A}^{36,41,46}$ & - & 1.3 & 2.8 & 1.0 & 1.0 & 0.9 & 1.0 & [71] \\
\hline Phospholamban- $\Delta^{1-25} A^{36,41,46}$ & - & 1.1 & 1.8 & 1.0 & 1.0 & 0.8 & 1.0 & [71] \\
\hline GalP & - & $1 \cdot 0,2 \cdot 9^{\mathrm{e}}$ & $1.9,4.3^{\mathrm{e}}$ & 1.0 & 0.9 & 1.0 & 1.0 & [89] \\
\hline Rhodopsin & 1.0 & 1.0 & 1.0 & 1.0 & 1.0 & 1.0 & 1.0 & {$[4,63]$} \\
\hline Gramicidin A & - & 1.2 & $0.7,1.4^{\mathrm{e}}$ & 1.1 & 0.8 & 0.8 & 1.0 & {$[72]$} \\
\hline$O m p A^{i}$ & - & 2.5 & $\sim 0.2$ & 0.6 & 1.0 & 0.5 & 0.6 & [77] \\
\hline OmpG & - & 1.2 & 0.7 & - & 1.1 & 0.9 & 1.0 & [78] \\
\hline FomA & - & 1.2 & 4.1 & 1.6 & 1.1 & 1.1 & 1.0 & [79] \\
\hline Fhu $A^{i}$ & - & 1.5 & 3.0 & 1.4 & 1.0 & 0.6 & 1.1 & [77] \\
\hline
\end{tabular}

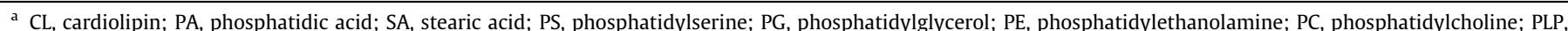
myelin proteolipid protein.

${ }^{b}$ Natural mixture of the proteolipid protein (PLP) and the DM-20 isoform (PLP- $\Delta^{116-150}$ ).

c In $\mathrm{diC}_{14: 0} \mathrm{PC}$.

d In $\operatorname{diC}_{14: 0} \mathrm{PG}$

e Values for protonated and charged forms, respectively.

${ }^{f} \beta$-Sheet form of the protein in $\mathrm{diC}_{14: 0} \mathrm{PC} / \mathrm{diC}_{14: 0} \mathrm{PG}(80: 20 \mathrm{~mol} / \mathrm{mol})$.

g $\alpha$-Helical (partly) form of the protein in $\operatorname{diC}_{14: 0} \mathrm{PC}$.

$\mathrm{h}$ Sequence: KLEALYILMVLGFFGFFTLGIMLSYIR.

i Relative to PG. 


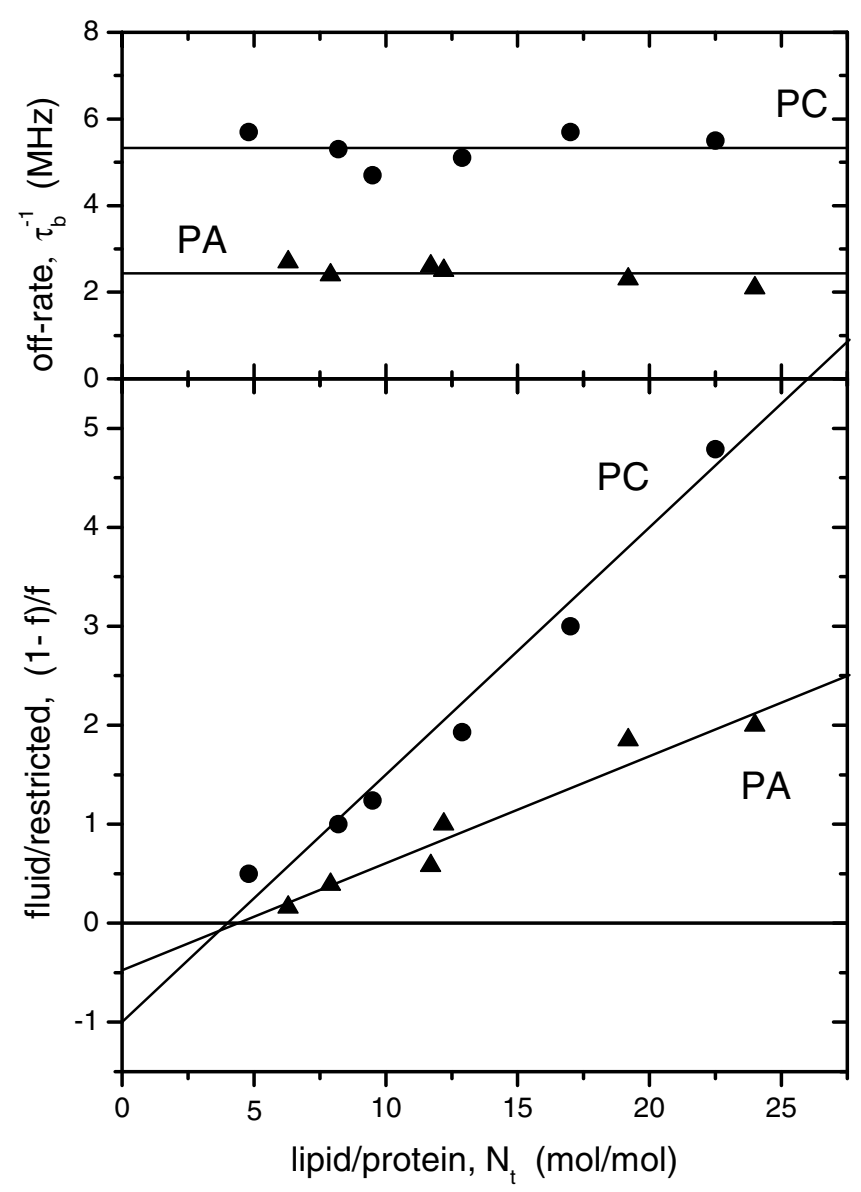

Fig. 4. (Lower panel): lipid/protein titration of M13 coat protein/diC $\mathrm{d}_{14: 0} \mathrm{PC}$ membranes from ESR difference spectra of the 14-PCSL (circles) and 14-PASL (triangles) spin-labels at $30^{\circ} \mathrm{C}$. $f$ is the fraction of motionally restricted spin-labelled lipid. For 14-PCSL: $N_{b}=4$ and $K_{r}=1$; for 14-PASL: $N_{b}=4.4$ and $K_{r}=2.1$ (see Eq. (1)). (Upper panel) Intrinsic off-rates, $\tau_{b}^{-1}$, for lipid-protein exchange of the 14-PCSL (circles) and 14-PASL (triangles) spin-labels at $30^{\circ} \mathrm{C}$ obtained from slow-motion two-site exchange spectral simulations. Data from Ref. [74].

Table 4

Stoichiometries, $N_{b}$ of first-shell lipids surrounding integral proteins from spin-label ESR, model building, and predictions of Eqs. (4)-(7)

\begin{tabular}{|c|c|c|c|c|c|c|}
\hline \multirow[t]{2}{*}{ Protein } & \multicolumn{6}{|c|}{$N_{b}(\mathrm{~mol} / \mathrm{mol})$} \\
\hline & ESR & Ref. & X-ray ${ }^{\mathrm{a}}$ & Ref. & Geometry & Eq. no. \\
\hline \multicolumn{7}{|l|}{$\alpha$-Helical } \\
\hline Rhodopsin & $22-25$ & {$[63-67]$} & $27 \pm 2$ & [94] & 24.5 & 4 \\
\hline ADP-ATP carrier & 25 & {$[68]$} & $28 \pm 2$ & [95] & 22.5 & 4 \\
\hline Ca-ATPase & $22-24$ & {$[96,97]$} & $28 \pm 4$ & [98] & 31 & 4 \\
\hline Na,K-ATPase & $32-33$ & {$[61,62,83]$} & - & - & 33 & 4 \\
\hline Cytochrome reductase & $38 \pm 3$ & [99] & $46 \pm 4$ & {$[100]$} & 37 & 4 \\
\hline $\begin{array}{l}\text { Nicotinic acetylcholine } \\
\text { receptor }\end{array}$ & $41 \pm 7$ & {$[31,101]$} & $52 \pm 4$ & {$[102]$} & 52 & 4 \\
\hline Cytochrome oxidase & $56 \pm 5$ & {$[59,60]$} & $\begin{array}{l}57 \pm 4 \\
43 \pm 4^{b}\end{array}$ & [103] & $\begin{array}{l}68.5 \\
63\end{array}$ & $\begin{array}{l}4 \\
6^{b}\end{array}$ \\
\hline Phospolamban L37A & $11.8 \pm 0.6$ & [104] & & & 10 & 5 \\
\hline M13 coat protein & $4-5$ & [73] & & & 4 & $6^{\mathrm{c}}$ \\
\hline Myelin proteolipid & $10 \pm 2$ & [69] & & & 10 & $6^{c}$ \\
\hline 16-kDa proteolipid & $5-6$ & {$[70]$} & & & 10 & $6^{\mathrm{c}}$ \\
\hline \multicolumn{7}{|l|}{$\beta$-Barrel } \\
\hline OmpA & 11 & [77] & $20 \pm 2$ & [162] & 11 & 7 \\
\hline OmpG & $20 \pm 1$ & [78] & & & 19 & 7 \\
\hline Fhua & 32 & [77] & $34 \pm 2$ & [163] & 30 & 7 \\
\hline
\end{tabular}

a Deduced from crystal structures (references given) by modelling, from Ref. [93].

b Value per monomer deduced from structure of dimer [93].

c Predictions for hexamer: $n_{\text {agg }}=6$.
$N_{b}=n_{\beta} D_{\beta} /\left(d_{c h} \cos \theta_{\beta}\right)$

where $D_{\beta}=0.47 \mathrm{~nm}$ is the interstrand separation, $\theta_{\beta}$ is the tilt angle of the $\beta$-strand relative to the membrane normal, and $n_{\beta}$ is the number of $\beta$-strands. Because $\beta$-strands are much more extended peptide structures than are $\alpha$-helices, a tilt of $\theta_{\beta} \approx 60^{\circ}$ is required for the same number of non-polar residues to be accommodated within the membrane as for an $\alpha$-helix. Eq. (7) performs reasonably well in predicting the stoichiometry of motionally restricted lipids for $\beta$ barrel outer membrane proteins from Escherichia coli [78,77], when combined with measurements of the strand tilt by polarised infrared spectroscopy [109-112] (see Table 4).

\section{Interpretation of lipid selectivities}

The exchange equilibrium for labelled, $\mathrm{L}^{*}$, and non-labelled, $\mathrm{L}$, lipids competing for the $N_{b}$ sites in the first shell at the intramembranous surface of the protein, $P$, can be depicted as:

$\mathrm{P} \cdot \mathrm{L}_{N_{b}}+\mathrm{L}^{*} \stackrel{K_{r}}{\leftrightarrow} \mathrm{P} \cdot \mathrm{L}_{N_{b}-1} \mathrm{~L}^{*}+\mathrm{L}$

The equilibrium constant for association of lipid $\mathrm{L}^{*}$ at first-shell sites, relative to that of the background lipid L, is given by:

$K_{r}=\frac{\left[\mathrm{L}^{*} \mathrm{P}\right][\mathrm{L}]}{[\mathrm{LP}]\left[\mathrm{L}^{*}\right]}$

This is related to the free energy of association, $\Delta G_{a s s}\left(L^{*}\right)$, by:

$\Delta \Delta G_{\text {ass }}=\Delta G_{\text {ass }}\left(\mathrm{L}^{*}\right)-\Delta G_{\text {ass }}(\mathrm{L})=-R T \ln K_{r}$

where $T$ is the absolute temperature and $R$ is the ideal gas constant.

It should be noted that the relative association constants obtained from ESR with spin-labelled lipids at probe concentrations represent an average over all sites, $i$, at the lipid-protein interface:

$K_{r}=\frac{1}{N_{b}} \sum_{i=1}^{N_{b}} K_{r, i}$

where $K_{r, i}$ is the relative association constant at site $i$. Therefore, a small number of highly specific sites cannot be distinguished from a smaller, but generalized, specificity for all $N_{b}$ sites at the lipidprotein interface. If the selective lipid is present at greater than probe concentrations, the equation for equilibrium lipid exchange association with the protein is no longer the approximation given in Eq. (1) but becomes [82,83]:

$\left(\frac{1-f}{f}\right) \sum_{i=1}^{N_{b}} \frac{K_{r, i}}{\left[f+K_{r, i}(1-f)\right] N_{t}^{*}+N_{t}-N_{b}}=1$

where $N_{t}^{*}$ is the lipid/ratio of specific $\left(\mathrm{L}^{*}\right)$ lipids and $N_{t}$ is that of the non-specific (L) lipids. In the case of cardiolipin (CL) interacting with cytochrome $c$ oxidase, higher concentrations of cardiolipin were used, but no saturation of highly specific sites was observed according to Eq. (11) [113].

The importance of lipid selectivities within the more general context of both hydrophobic matching and transmembrane lateral pressure profiles has been discussed recently $[2,114,115]$.

\section{Lipid exchange rates at the interface with transmembrane proteins}

The rate of exchange of spin-labelled lipids at the intramembranous surface of the protein can be estimated by simulating the two-component ESR lineshapes and linewidths with a two-site slow-exchange model for lipid $\mathrm{L}^{*}[116,117]$ :

$\mathrm{P} \cdot \mathrm{L}_{N_{b}}+\mathrm{L}^{*} \underset{\tau_{b}^{-1}}{\stackrel{\tau_{f}^{-1}}{\rightleftarrows}} \mathrm{P} \cdot \mathrm{L}_{N_{b}-1} \mathrm{~L}^{*}+\mathrm{L}$ 
i.e., $\mathrm{L}_{f}^{*} \underset{\tau_{b}^{-1}}{\stackrel{\tau_{f}^{-1}}{\rightleftarrows}} \mathrm{L}_{b}^{*}$

where $\tau_{f}^{-1}$ is the on-rate and $\tau_{b}^{-1}$ is the off-rate for the spin-labelled lipid $\mathrm{L}^{*}$. If $f$ is the fraction of $\mathrm{L}^{*}$ associated with the protein, the slowexchange ESR absorption lineshape that is required for spectral simulation is given by:

$v(\omega) \propto \frac{f\left(T_{2, b}^{-1}+\tau_{b}^{-1}\right)}{\left(T_{2, b}^{-1}+\tau_{b}^{-1}\right)^{2}+\left(\omega_{b}-\omega\right)^{2}}+\frac{(1-f)\left(T_{2, f}^{-1}+\tau_{f}^{-1}\right)}{\left(T_{2, f}^{-1}+\tau_{f}^{-1}\right)^{2}+\left(\omega_{f}-\omega\right)^{2}}$

where $\omega_{b}$ and $\omega_{f}$ are the angular resonance frequencies of the motionally restricted and fluid lipid components, respectively, and $\tau_{b}^{-1}, \tau_{f}^{-1} \leqslant\left(\omega_{b}-\omega_{f}\right)$. Material balance requires that the lipid flow in both directions is equal at equilibrium:

$f \tau_{b}^{-1}=(1-f) \tau_{f}^{-1}$

where $\tau_{b}^{-1}$ is the intrinsic exchange rate that depends on the affinity of $\mathrm{L}^{*}$ for the protein (i.e., on $K_{r}$ ), and is independent of the lipid-protein ratio (see upper panel of Fig. 4). The on-rate, on the other hand, is diffusion-controlled and depends on the size of the free pool of lipid according to Eq. (13). The reliability of two-site slow-motional simulations can be improved by fitting measurements at different microwave frequencies which changes the relative values of the resonance frequencies $\omega_{b}$ and $\omega_{f}$ [117].

More sensitive estimation of the exchange rate than is possible from slow-exchange lineshapes comes from ESR saturation experiments because these are optimally matched in time-scale to lipid exchange processes [118-121]. The increase in spin-lattice relaxation rate of the protein-associated lipids that arises from exchange with the fluid lipid population is given by [122]:

$\Delta\left(\frac{1}{T_{1, b}}\right)=\frac{1}{T_{1, b}}-\frac{1}{T_{1, b}^{o}}=\frac{\tau_{b}^{-1}}{1+T_{1, f}^{o} \tau_{f}^{-1}}$

where $T_{1, b}^{o}$ and $T_{1, f}^{o}$ are the spin-lattice relaxation times of the motionally restricted and fluid lipids, respectively, in the absence of exchange. An analogous expression holds for the relaxation enhancement, $\Delta\left(1 / T_{1, f}\right)$, of the fluid lipids. In a progressive (CW) saturation experiment, the dependence of the double-integrated intensity of the two-component spectrum on the microwave field strength, $H_{1}$, is given by $[123,124]$ :

$S\left(H_{1}\right)=S_{o} H_{1}\left(\frac{f}{\sqrt{1+\sigma_{b}}}+\frac{1-f}{\sqrt{1+\sigma_{f}}}\right)$

where $\sigma_{b}=\gamma_{e}^{2} H_{1}^{2} T_{1, b} T_{2, b}$ and similarly for $\sigma_{f}$ $\left(\gamma_{e}=1.76084 \times 10^{7} \mathrm{rad} \mathrm{s}^{-1} \mathrm{G}^{-1}\right)$. The linewidths, $1 / T_{2, b}$ and $1 / T_{2, f}$, correspond to the slow exchange condition (as noted above) and therefore do not change greatly compared with the spin-lattice relaxation rates, $1 / T_{1, b}$ and $1 / T_{1, f}$. Combination of Eq. (13) with Eqs. (14) and (15), and equivalents, thus allows determination of the exchange rate $T_{1, b}^{o} \tau_{b}^{-1}$ that is normalised with respect to the intrinsic spin-lattice relaxation time: $T_{1, b}^{o} \sim 1 \mu \mathrm{s}$ [122]. For further experimental details on saturation transfer ESR and progressive saturation studies, see [124,125].

Reference data on the intrinsic off-rate constants $\left(\tau_{b, o}^{-1}\right)$ for exchange of phosphatidylcholine (a lipid that does not express selectivity for the protein) at the interface with different membrane proteins are listed in Table 5. For comparison, the intrinsic diffusional lipid-lipid exchange rates in fluid phosphatidylcholine bilayers are $\tau_{\text {diff }}^{-1} \approx 8 \times 10^{7} \mathrm{~s}^{-1}[126,127]$. The rates of exchange at the protein interface are such that ${ }^{2} \mathrm{H}$-labelled lipids would be in fast exchange on the quadrupolar NMR time-scale, explaining why only single-component lipid spectra are observed in lipidprotein systems by solid-state NMR [128].
Table 5

Reference data: off-rate constants $\tau_{b o}^{-1}$ and activation energies $\left(E_{a, o}\right)$ for exchange of phosphatidylcholine (14-PCSL) at the intramembranous surface of different transmembrane proteins ${ }^{\mathrm{a}}$

\begin{tabular}{|c|c|c|c|c|}
\hline Protein/lipid & $T\left({ }^{\circ} \mathrm{C}\right)$ & $\tau_{b, o}^{-1}\left(\mathrm{~s}^{-1}\right)$ & $E_{a, o}(\mathrm{~kJ} / \mathrm{mol})$ & Ref. \\
\hline Myelin proteolipid protein/ $\mathrm{diC}_{14: 0} \mathrm{PC}$ & 30 & $1.6 \times 10^{7}$ & 20 & {$[116,129$} \\
\hline Myelin DM-20 protein/diC $\mathrm{d}_{14: 0} \mathrm{PC}$ & 30 & $1.5 \times 10^{7}$ & - & {$[84]$} \\
\hline ADP-ATP carrier/egg PC & 10 & $1.4 \times 10^{7}$ & - & [68] \\
\hline M13 coat protein( $\alpha$-helix)/diC 18:1c $\mathrm{PC}$ & 24 & $3.0 \times 10^{7}$ & - & [73] \\
\hline M13 coat protein $(\alpha$-helix $) /$ diC $_{14: 0}$ PC & 30 & $2.3 \times 10^{7}$ & - & [73] \\
\hline M13 coat protein $(\beta$-sheet $) / \mathrm{diC}_{14: 0} \mathrm{PC}$ & 30 & $5.3 \times 10^{6}$ & - & [74] \\
\hline Rhodopsin/ $\mathrm{diC}_{14: 0} \mathrm{PC}$ & 30 & $1.6 \times 10^{7}$ & 20 & {$[65]$} \\
\hline
\end{tabular}

a Values determined by two-site slow-exchange simulations of ESR lineshapes.

Compared to the non-selective reference lipid with relative association constant $K_{r, o}$, the intrinsic off-rate of a lipid that expresses selectivity $\left(K_{r}\right)$ for the protein is given by $[116,129]$ :

$\frac{\tau_{b}^{-1}}{\tau_{b, o}^{-1}}=\frac{K_{r, o}}{K_{r}}$

This inverse dependence on relative association constant reflects the simple fact that lipids displaying selectivity reside longer at the protein interface than does phosphatidylcholine. The off-rates are correspondingly slower and can be estimated from Eq. (16) by combining data from Tables 3 and 5 .

Although exchange rates are too slow to be measured in lipid gel phases, saturation measurements are able to study the stoichiometry and selectivity of lipid-protein interactions in gel-phase membranes, for which two-components are not easily resolved in the conventional ESR spectra $[119,130,131]$.

\section{Membrane-penetrant proteins}

The two-component spectra of probe lipids spin-labelled on the C14 position of the hydrocarbon chain (14-PXSL, 14-SASL) also can be used to detect partial penetration of surface-binding proteins into the hydrophobic membrane core. In these cases, the stoichiometry of motionally restricted lipids $\left(N_{b}\right)$ obtained from spectral subtractions provides a means to estimate the extent of membrane-penetration or insertion (see Eqs. (4)-(7)). The motionally restricted component is not necessarily so strongly immobilized as in the case of transmembrane proteins, and this requires careful choice of the matching single-component spectrum [132]. Because the stoichiometry of motionally restricted lipids generally is less than that for transmembrane proteins, C12-position labels (for which the relative lineheights of fluid and motionally restricted lipids are more comparable) may be better than the C14-position labels for quantifying the degree of membrane-penetration (see, e.g., $[132,133])$.

The extent of motional restriction is measured by the outer hyperfine splitting, $2 A_{\max }$, of the C14-position (or C12-position) spin-label. In general, $A_{\max }$ is dependent on both the amplitude (i.e., order) and rate of chain rotational motion [134,135], and is thereby a useful parameter for characterising lipid chain dynamics under all conditions of immobilisation [136,137]. This, therefore, also provides a comparative index of the extent of membrane penetration: from superficial to completely transmembrane. Reference values of $2 A_{\max }$ for the motionally restricted component of C14-position spin-labels are given in Table 6 , for different proteins associated at the surface of anionic lipid bilayers. Myelin proteolipid protein and cytochrome $c$ oxidase are included in the table as examples of proteins that are fully transmembrane. The work referenced in Table 6 provides ready access to the range of two-component ESR lineshapes that may be encountered with different degrees of protein penetration into the membrane. 
Table 6

Reference data: outer hyperfine splittings, $2 A_{\max }$, of the motionally restricted component in the ESR spectra of lipids spin-labelled on the C14-position of the sn2 chain (14-PGSL) in interaction with membrane-penetrating peripheral proteins

\begin{tabular}{|c|c|c|c|c|}
\hline Protein & Lipid & $T\left({ }^{\circ} \mathrm{C}\right)$ & $2 A_{\max }(\mathrm{G})$ & Ref. \\
\hline Myelin proteolipid protein ${ }^{a}$ & $\mathrm{diC}_{14: 0} \mathrm{PC}$ & 30 & 62.8 & [69] \\
\hline Cytochrome $c$ oxidase $\mathrm{a}^{\mathrm{a}}$ & $\mathrm{diC}_{14: 0} \mathrm{PC}$ & 30 & 60.9 & [59] \\
\hline $\begin{array}{l}\text { Bovine seminal plasma } \\
\text { protein PDC-109b }\end{array}$ & $\operatorname{diC}_{14: 0} \mathrm{PC}$ & 28 & 59.5 & {$[138,139]$} \\
\hline$\alpha$-Lactalbumin, $\mathrm{pH} 4$ & $\mathrm{diC}_{18: 1} \mathrm{PG}$ & 20 & 61 & [140] \\
\hline Diphtheria toxin, pH 5 & $\mathrm{diC}_{18: 1} \mathrm{PG}$ & 10 & 61 & [141] \\
\hline $\begin{array}{l}\text { Cytochrome Oxidase } \\
\text { subunit IV presequence }^{c}\end{array}$ & $\mathrm{diC}_{18: 1} \mathrm{PG}$ & 5 & 59 & [142] \\
\hline $\sec A(E$. coli $)$ & $\mathrm{diC}_{18: 1} \mathrm{PG}$ & 20 & 57 & [143] \\
\hline PhoE precursor (E. coli) & $\mathrm{diC}_{18: 1} \mathrm{PG}$ & 20 & 56 & [144] \\
\hline Myelin basic protein & $\mathrm{diC}_{14: 0} \mathrm{PG}$ & 30 & 53 & [145] \\
\hline Apocytochrome $c$ & Brain PS & 30 & 49.5 & {$[132,146,147]$} \\
\hline Lipid alone & & & $33-34$ & \\
\hline
\end{tabular}

a Integral transmembrane proteins.

b 14-PCSL: PDC 109 displays a preferential interaction with PC.

c Sequence: MLSLRQSIRFFKPATRTLCSSRYLL-CONH ${ }_{2}$.

\section{Surface-binding proteins}

Proteins that associate at the membrane surface but do not penetrate into the hydrophobic core give rise only to single-component ESR spectra of the spin-labelled lipid chains. In general, binding at the membrane surface causes a limited perturbation in mobility of the lipid chains throughout the membrane. This reflects changes in lipid packing density that arise from association of the protein with the lipid polar groups. These perturbations are registered by changes, $2 \Delta A_{\max }$, in the outer hyperfine splitting of spin-labels at the $C 5$-position in the lipid chains (see Fig. 5). Table 7 lists reference data on $2 \Delta A_{\max }$ of non-selective C5-position spin-labelled lipids, for a range of surface-binding proteins. For comparison, proteins that partially penetrate the membrane are included, in addition to those that associate purely at the surface. At the C5-position, $2 A_{\max }$ is sufficiently large in fluid lipid bilayers that two-component spectra are not resolved with membrane-penetrant proteins. The references in Table 7 give access to the range of spectral lineshapes for C5-position spin-labelled lipids that are encountered in fluid membranes, on the surface-association of peripheral proteins.

It is evident from Fig. 5 that the value of $2 \Delta A_{\max }$ depends on the nature of the polar headgroup of the $\mathrm{C} 5$-position spin-labelled lipid. In general, the data given in Table 7 are for 5-PGSL in membranes of phosphatidylglycerol and for 5-PCSL in membranes of phosphatidylcholine, such that headgroup specificities are minimised. Many of the proteins in Table 7 are strongly basic and require negatively charged lipids for membrane binding. In cases for which association also takes place with zwitterionic phosphatidylcholine membranes, the values of $2 \Delta A_{\max }$ are mostly smaller than those for binding to anionic phosphatidylglycerol membranes (with the exception of the bovine seminal plasma PC-binding protein PDC 109).

Note that $2 A_{\max }$ is a very useful parameter for following protein binding. In a protein-lipid titration, $2 A_{\max }$ increases progressively with increasing protein/lipid ratio until a saturation value is reached, much as in a conventional binding curve [132,149]. Extrapolation of the initial, approximately linear, dependence of $2 A_{\max }$ on protein/ lipid ratio to the saturation level provides an estimate for the stoichiometry of protein binding at saturation (see Fig. 6).

\section{Analysis of in-plane lipid associations with membrane- bound proteins}

Differences in $2 \Delta A_{\max }$ for different C5-position spin-labelled species (5-PXSL) reflect the selectivity of the different lipid head-

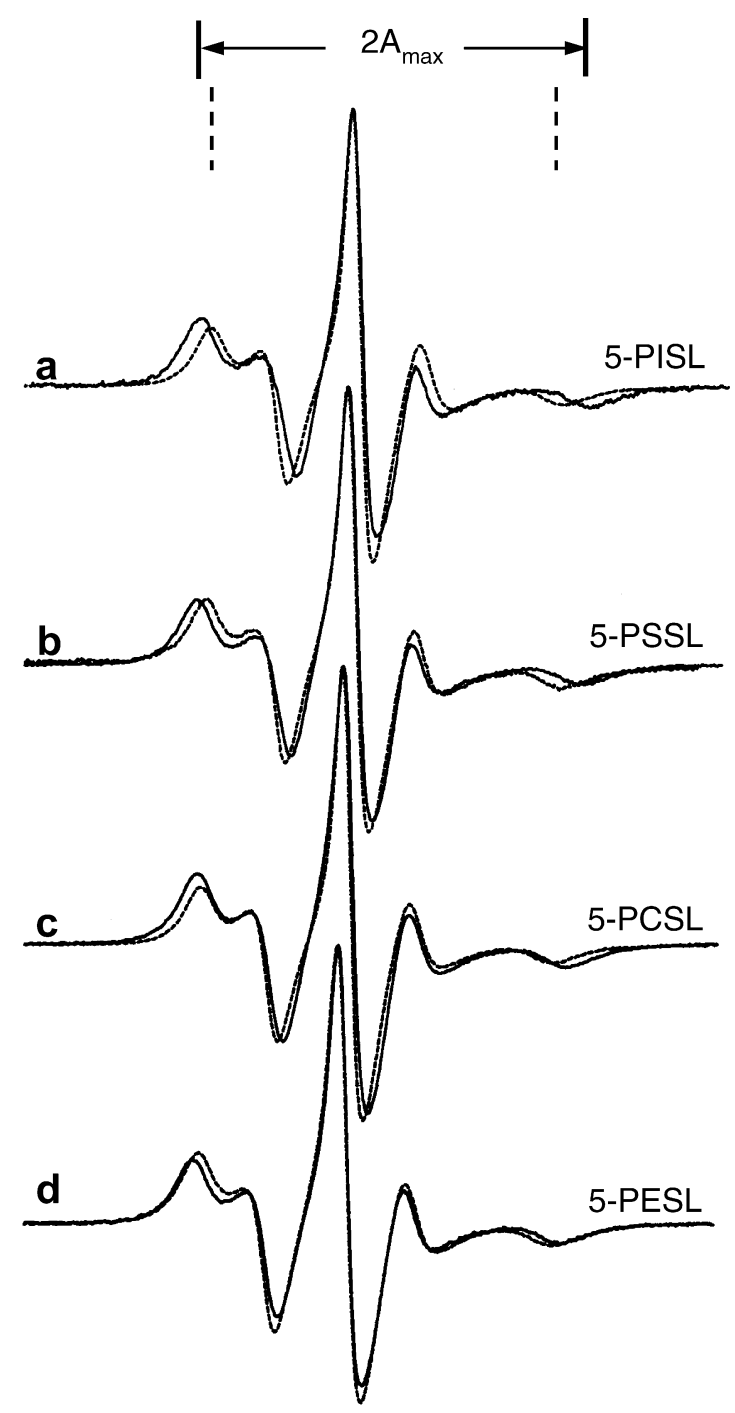

Fig. 5. ESR spectra of C5-position spin-labelled phospholipids in fluid-phase membranes of $\mathrm{diC}_{14: 0} \mathrm{PG}$ in the presence (solid lines) and absence (dotted lines) of a saturating amount of bound apocytochrome $c$. (a) Phosphatidylinositol, 5-PISL; (b) phosphatidylserine, 5-PSSL; (c) phosphatidylcholine, 5-PCSL; and (d) phosphatidylethanolamine, 5-PESL. The outer hyperfine splitting, $2 A_{\max }$, is indicated by vertical lines. $T=30^{\circ} \mathrm{C}$. Spectral width $=100 \mathrm{G}$. Data from Ref. [148].

groups for interaction with the surface-bound protein [148]. It should be emphasised that these selectivities are for proteins that are already present at the membrane surface, and therefore may differ considerably from the pattern of lipid specificity that is required for membrane binding of the free protein (cf. $[157,158]$ ).

Assume that the bound protein has $N_{p}$ lipid sites at its membrane-facing surface. These sites are characterised by a relative association constant for $\mathrm{C} 5$-position spin-labelled lipids that is defined in Eq. (8). For probe amounts of spin-labelled lipid, the fraction $f$ that is associated at one of the protein sites is given by:

$f=\frac{K_{r}}{N_{t} / N_{p}-1+K_{r}}$

which is obtained directly from Eq. (1) with $N_{p} \equiv N_{b}$.

Assuming fast exchange between free and protein-associated sites, the increase in hyperfine splitting constant, $\Delta A_{\max }=A_{\max }-A_{\max }^{f}$, on lipid-protein interaction is given by [150]:

$\Delta A_{\max }=f \Delta A_{\max }^{b}$ 
Table 7

Reference data: increase in outer hyperfine splittings, $2 \Delta A_{\max }$, of phospholipid probes spin-labelled at the C5-position of the sn-2 chain (5-PGSL or 5-PCSL) on adding saturating amounts of surface-associating proteins or peptides to fluid phospholipid membranes

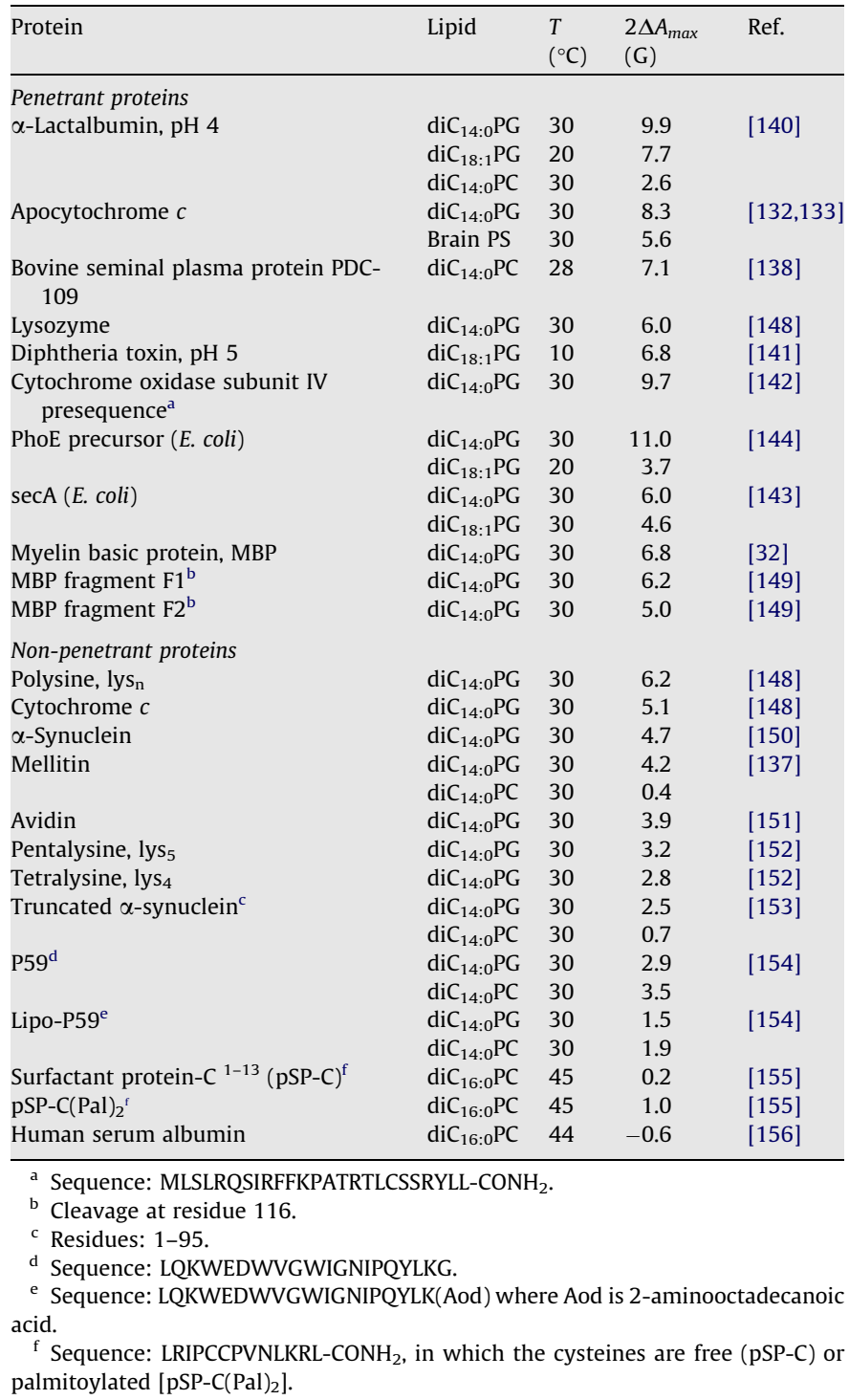

palmitoylated $\left[\mathrm{pSP}-\mathrm{C}(\mathrm{Pal})_{2}\right]$

where $A_{\max }^{b}$ and $A_{\max }^{f}$ are values of $A_{\max }$ for the bound and free lipid, respectively, and $\Delta A_{\max }^{b}=A_{\max }^{b}-A_{\max }^{f}$ is the intrinsic difference in hyperfine splitting between free and protein-associated sites. Combining Eqs. (17) and (18) gives the following expression for the relative association constant of the spin-labelled lipid:

$K_{r}=\left(\frac{N_{t}}{N_{p}}-1\right) \frac{1}{\Delta A_{\max }^{b} / \Delta A_{\max }-1}$

Compared to a non-selective reference lipid (e.g., phosphatidylglycerol) with relative association constant $K_{r, o}$, the association constants are then related to the increases, $2 \Delta A_{\max }$, in outer hyperfine splitting by:

$\frac{K_{r}}{K_{r, o}}=\frac{\Delta A_{\max }^{b} / \Delta A_{\max , o}-1}{\Delta A_{\max }^{b} / \Delta A_{\max }-1}$

where $2 \Delta A_{\max , o}$ is the increase in outer hyperfine splitting for the reference lipid. The problem is to find the intrinsic value of $\Delta A_{\max }^{b}$

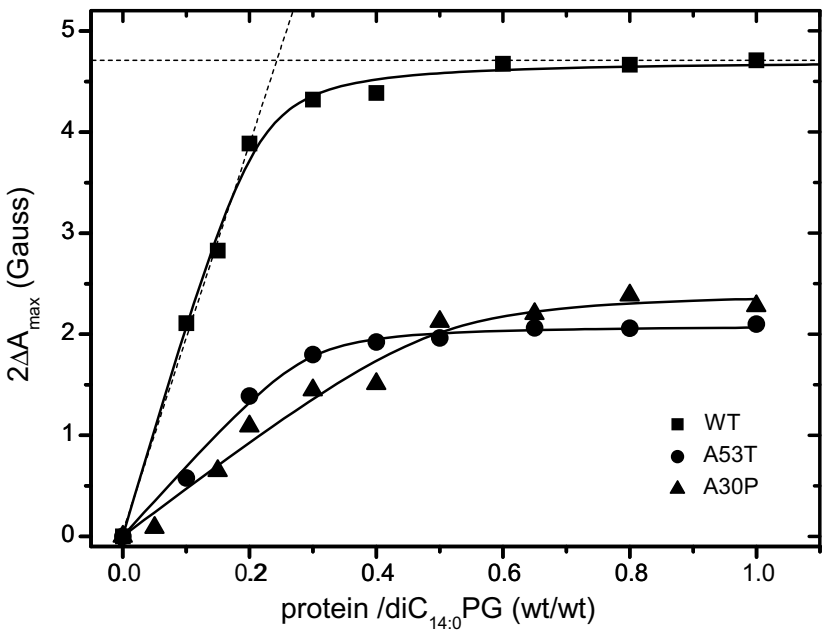

Fig. 6. Dependence of the increase in outer hyperfine splitting, $2 \Delta A_{\max }$, of 5-PGSL on the $\alpha$-synuclein/lipid ratio in $\mathrm{diC}_{14 \cdot 0} \mathrm{PG}$ membranes at $30^{\circ} \mathrm{C}$. Data are given for binding of wild-type $\alpha$-synuclein (squares) and the early-onset Parkinson's disease mutants, A53T (circles) and A30P (triangles). Dashed lines indicate the initial linear slope for complete binding and the constant saturation level at high protein/lipid ratio, for the wild-type protein. Data from Refs. [150,153].

for the bound species. The value of $\Delta A_{\max }$ for the lipid displaying highest selectivity provides an approximate (lower) estimate [153]; an upper bound is obtained from the rigid limit value of $2 A_{\max }$. Further details can be found in Refs. [32,150].

\section{Conclusion}

Finally, it is possible to combine both ESR methods for studying lipid-protein interactions by progressively binding peripheral proteins to reconstituted membranes containing integral proteins at different lipid/protein ratios [15,16], e.g., binding of myelin basic protein to phosphatidylglycerol membranes containing the myelin proteolipid protein [85]. Examples of other membrane protein couples that have been studied in this way are: cytochrome $c$ and cytochrome $c$ oxidase [60]; melittin and SERCA Ca-ATPase in sarcoplasmic reticulum membranes [159]; and biotin-PE conjugated to avidin together with myelin proteolipid protein [160]

\section{References}

[1] A. Watts, J. Davoust, D. Marsh, P.F. Devaux, Biochim. Biophys. Acta 643 (1981) 673-676

[2] D. Marsh, Biochim. Biophys. Acta 1778 (2008) 1545-1575.

[3] D. Marsh, A. Watts, Methods Enzymol. 88 (1982) 762-772.

[4] D. Marsh, A. Watts, R.D. Pates, R. Uhl, P.F. Knowles, M. Esmann, Biophys. J. 37 (1982) 265-274.

[5] D. Marsh, Trends Biochem. Sci. 8 (1983) 330-333.

[6] D. Marsh, J. Bioenerg. Biomembr. 19 (1987) 677-689.

[7] D. Marsh, G.L. Powell, Bioelectrochem. Bioenerg. 20 (1988) 73-82.

[8] D. Marsh, FEBS Lett. 268 (1990) 371-375.

[9] P.F. Knowles, D. Marsh, Biochem. J. 274 (1991) 625-641.

[10] D. Marsh, Curr. Opin. Struct. Biol. 2 (1992) 497-502.

[11] D. Marsh, Mol. Membr. Biol. 12 (1995) 59-64.

[12] D. Marsh, Biochem. J. 315 (1996) 345-361.

[13] D. Marsh, Curr. Opin. Coll. Intf. Sci. 2 (1997) 4-14

[14] D. Marsh, L.I. Horváth, Biochim. Biophys. Acta 1376 (1998) 267-296.

[15] D. Marsh, L.I. Horváth, M.J. Swamy, S. Mantripragada, J.H. Kleinschmidt, Mol. Membr. Biol. 19 (2002) 247-255.

[16] D. Marsh, T. Páli, Biochim. Biophys. Acta 1666 (2004) 118-141.

[17] M. Esmann, D. Marsh, Chem. Phys. Lipids 141 (2006) 94-104.

[18] J.S. Hyde, W. Fronciscz, in: A.J. Hoff (Ed.), Advanced EPR, Applications in Biology and Biochemistry, Elsevier, Amsterdam, 1989, pp. 277-305.

[19] D. Marsh, in: J.C. Metcalfe, T.R. Hesketh (Eds.), Techniques in Lipid and Membrane Biochemistry, vol. B4/II, Elsevier, 1982, pp. B426/1-B426/44.

[20] P.F. Knowles, D. Marsh, H.W.E. Rattle, Magnetic Resonance of Biomolecules, Wiley-Interscience, London, 1976.

[21] W.L. Hubbell, H.M. McConnell, J. Am. Chem. Soc. 93 (1971) 314-326. 
[22] A.S. Waggoner, T.J. Kingzett, S. Rottschaefer, O.H. Griffith, A.D. Keith, Chem Phys. Lipids 3 (1969) 245-253.

[23] D. Marsh, A. Watts, in: P.C. Jost, O.H. Griffith (Eds.), Lipid-Protein Interactions, vol. 2, Wiley-Interscience, New York, 1982, pp. 53-126.

[24] J.F.W. Keana, S.B. Keana, D. Beetham, J. Am. Chem. Soc. 89 (1967) 3055-3056

[25] K. Hideg, L. Lex, J. Chem. Soc., Chem. Commun. (1984) 1265.

[26] K. Hideg, L. Lex, J. Chem. Soc., Perkin Trans. 1 (1986) 1431-1438.

[27] T. Heimburg, K. Hideg, D. Marsh, J. Phys. Chem. 95 (1991) 1950-1956.

[28] M. Esmann, K. Hideg, D. Marsh, Biochemistry 27 (1988) 3913-3917.

[29] W.F. Boss, C.J. Kelley, F.R. Landsberger, Anal. Biochem. 64 (1975) 289-292.

[30] J.T. Mason, A.V. Broccoli, C.-H. Huang, Anal. Biochem. 113 (1981) 96-101.

[31] S. Mantipragada, L.I. Horváth, H.R. Arias, G. Schwarzmann, K. Sandhoff, F.J. Barrantes, D. Marsh, Biochemistry 42 (2003) 9167-9175.

[32] M.B. Sankaram, P.J. Brophy, D. Marsh, Biochemistry 28 (1989) 9699-9707.

[33] P. Somerharju, K.W. Wirtz, Chem. Phys. Lipids 30 (1982) 81-91.

[34] P. Comfurius, R.F.A. Zwaal, Biochim. Biophys. Acta 488 (1977) 36-42.

[35] M.B. Cable, J. Jacobus, G.L. Powell, Proc. Natl. Acad. Sci. USA 75 (1978) 1227 1231.

[36] G.L. Powell, P.F. Knowles, D. Marsh, Biochemistry 26 (1987) 8138-8145.

[37] M. Esmann, G.L. Powell, D. Marsh, Biochim. Biophys. Acta 941 (1988) 287292

[38] P. Hoffmann, K. Sandhoff, D. Marsh, Biochim. Biophys. Acta 1468 (2000) 359366.

[39] Y. Lapidot, S. Rappoport, Y. Wolman, J. Lipid Res. 8 (1967) 142-145.

[40] Y. Barenholz, S. Gatt, in: A. Hawthorne (Ed.), Phospholipids, Elsevier Biomedical Press, Amsterdam/London/New York, 1982, pp. 129-177.

[41] G. Schwarzmann, K. Sandhoff, Methods Enzymol. 138 (1987) 319-341.

[42] M. Esmann, D. Marsh, G. Schwarzmann, K. Sandhoff, Biochemistry 27 (1988) 2398-2403.

[43] I. Nishida, M. Yamada, Biochim. Biophys. Acta 813 (1985) 298-306.

[44] G. Li, L.I. Horváth, P.F. Knowles, D.J. Murphy, D. Marsh, Biochim. Biophys. Acta 987 (1989) 187-192.

[45] G. Li, P.F. Knowles, D.J. Murphy, I. Nishida, D. Marsh, Biochemistry 28 (1989) 7446-7452.

[46] G. Li, P.F. Knowles, D.J. Murphy, D. Marsh, Biochim. Biophys. Acta 1024 (1990) $278-284$

[47] J. Miyazaki, K. Hideg, D. Marsh, Biochim. Biophys. Acta 1103 (1992) 62-68.

[48] K. Hideg, L. Lex, H.O. Hankovsky, J. Tigyi, Synthetic Comm. 9 (1979) 781788.

[49] L.I. Horváth, H.R. Arias, H.O. Hankovszky, K. Hideg, F.J. Barrantes, D. Marsh, Biochemistry 29 (1990) 8707-8713.

[50] N. Dixon, T. Páli, S. Ball, M.A. Harrison, D. Marsh, J.B.C. Findlay, T.P. Kee, Org Biomol. Chem. 1 (2003) 4361-4363.

[51] N. Dixon, T. Páli, T.P. Kee, D. Marsh, Biochim. Biophys. Acta 1665 (2004) 177183.

[52] N. Dixon, T. Páli, T.P. Kee, S. Ball, M.A. Harrison, J.B.C. Findlay, J. Nyman, H.K Väänänen, M.E. Finbow, D. Marsh, Biophys. J. 94 (2008) 506-514.

[53] P. Fretten, S.J. Morris, A. Watts, D. Marsh, Biochim. Biophys. Acta 598 (1980) 247-259.

[54] R. Bartucci, T. Páli, D. Marsh, Biochemistry 32 (1993) 274-281.

[55] K. Schorn, D. Marsh, Biochemistry 35 (1996) 3831-3836.

[56] M.J. Swamy, D. Marsh, Biochemistry 36 (1997) 7403-7407.

[57] E.G. Bligh, W.J. Dyer, Can. J. Biochem. Physiol. 37 (1959) 911-917.

[58] Z. Kóta, T. Páli, N. Dixon, T.P. Kee, M. Harrison, J.B.C. Findlay, M.E. Finbow, D. Marsh, Biochemistry 47 (2008) 3937-3949.

[59] P.F. Knowles, A. Watts, D. Marsh, Biochemistry 18 (1979) 4480-4487.

[60] J.H. Kleinschmidt, G.L. Powell, D. Marsh, Biochemistry 37 (1998) 1157911585.

[61] M. Esmann, A. Watts, D. Marsh, Biochemistry 24 (1985) 1386-1393.

[62] M. Esmann, K. Hideg, D. Marsh, in: J.C. Skou, J.G. Norby, A.B. Maunsbach, M Esmann (Eds.), The $\mathrm{Na}^{+}, \mathrm{K}^{+}$-Pump, Part A: Molecular Aspects, Progress in Clinical and Biological Research, vol. 268A, Alan Liss, New York, 1988, pp. 189-196.

[63] A. Watts, I.D. Volotovski, D. Marsh, Biochemistry 18 (1979) 5006-5013.

[64] R.D. Pates, D. Marsh, Biochemistry 26 (1987) 29-39.

[65] N.J.P. Ryba, L.I. Horváth, A. Watts, D. Marsh, Biochemistry 26 (1987) 32343240.

[66] N.J.P. Ryba, D. Marsh, Biochemistry 31 (1992) 7511-7518.

[67] R.D. Pates, A. Watts, R. Uhl, D. Marsh, Biochim. Biophys. Acta 814 (1985) 389397.

[68] L.I. Horváth, M. Drees, K. Beyer, M. Klingenberg, D. Marsh, Biochemistry 29 (1990) 10664-10669.

[69] P.J. Brophy, L.I. Horváth, D. Marsh, Biochemistry 23 (1984) 860-865.

[70] T. Páli, M.E. Finbow, A. Holzenburg, J.B.C. Findlay, D. Marsh, Biochemistry 34 (1995) 9211-9218.

[71] A. Arora, I.M. Williamson, A.G. Lee, D. Marsh, Biochemistry 42 (2003) 5151 5158.

[72] Z. Kóta, T. Páli, D. Marsh, Biophys. J. 86 (2004) 1521-1531.

[73] S.J.C.J. Peelen, J.C. Sanders, M.A. Hemminga, D. Marsh, Biochemistry 31 (1992) 2670-2677.

[74] C.J.A.M. Wolfs, L.I. Horváth, D. Marsh, A. Watts, M.A. Hemminga, Biochemistry 28 (1989) 9995-10001.

[75] L.I. Horváth, P.F. Knowles, P. Kovachev, J.B.C. Findlay, D. Marsh, Biophys. J. 73 (1997) 2588-2594

[76] L.I. Horváth, T. Heimburg, P. Kovachev, J.B.C. Findlay, K. Hideg, D. Marsh, Biochemistry 34 (1995) 3893-3898.
[77] M. Ramakrishnan, C.L. Pocanschi, J.H. Kleinschmidt, D. Marsh, Biochemistry 43 (2004) 11630-11636

[78] V. Anbazhagan, J. Qu, J.H. Kleinschmidt, D. Marsh, Biochemistry 47 (2008) 6189-6198.

[79] V. Anbazhagan, N. Vijay, J.H. Kleinschmidt, D. Marsh, Biochemistry 47 (2008) in press, doi:10.1021/bi800750s.

[80] O.H. Lowry, N.J. Rosebrough, L. Farr, R.J. Randall, J. Biol. Chem. 193 (1951) 265-275.

[81] H. Eibl, W.E.M. Lands, Anal. Biochem. 30 (1969) 51-57.

[82] D. Marsh, in: A. Watts, J.J.H.H.M. de Pont (Eds.), Progress in Protein-Lipid Interactions, vol. 1, Elsevier, Amsterdam, 1985, pp. 143-172.

[83] J.R. Brotherus, O.H. Griffith, M.O. Brotherus, P.C. Jost, J.R. Silvius, L.E. Hokin, Biochemistry 20 (1981) 5261-5267.

[84] L.I. Horváth, P.J. Brophy, D. Marsh, Biochemistry 29 (1990) 2635-2638.

[85] M.B. Sankaram, P.J. Brophy, D. Marsh, Biochemistry 30 (1991) 5866-5873.

[86] A. Arora, M. Esmann, D. Marsh, Biochim. Biophys. Acta 1371 (1998) 163167.

[87] P.F. Knowles, A. Watts, D. Marsh, Biochemistry 20 (1981) 5888-5894.

[88] K.P. Datema, C.J.A.M. Wolfs, D. Marsh, A. Watts, M.A. Hemminga, Biochemistry 26 (1987) 7571-7574.

[89] A. Hubert, P.J.F. Henderson, D. Marsh, Biochim. Biophys. Acta 1611 (2003) 243-248.

[90] D. Marsh, in: A. Watts (Ed.), New Comprehensive Biochemistry, Protein-Lipid Interactions, vol. 25, Elsevier, Amsterdam, 1993, pp. 41-66.

[91] D. Marsh, Eur. Biophys. J. 26 (1997) 203-208.

[92] R.F. Walters, W.F. DeGrado, Proc. Natl. Acad. Sci. USA 103 (2006) 1365813663.

[93] T. Páli, D. Bashtovyy, D. Marsh, Prot. Sci. 15 (2006) 1153-1161.

[94] T. Okada, Y. Fujiyoshi, M. Silow, J. Navarro, E.M. Landau, Y. Shichida, Proc. Natl. Acad. Sci. USA 99 (2002) 5982-5987.

[95] E. Pebay-Peyroula, C. Dahout-Gonzalez, R. Kahn, V. Trézéguet, G.J.M. Lauquin, G. Brandolin, Nature 426 (2003) 39-44.

[96] J.R. Silvius, D.A. McMillen, N.D. Saley, P.C. Jost, O.H. Griffith, Biochemistry 23 (1984) 538-547.

[97] D.D. Thomas, D.J. Bigelow, T.J. Squier, C. Hidalgo, Biophys. J. 37 (1982) 217225

[98] C. Toyoshima, M. Nakasako, N. Nomura, H. Ogawa, Nature 405 (2000) 647655.

[99] G.L. Powell, C.-A. Yu, D. Marsh, to be published.

[100] X. Gao, X. Wen, C.-A. Yu, L. Esser, S. Tsao, B. Quinn, L. Zhang, L. Yu, D. Xia, Biochemistry 41 (2002) 11692-11702.

[101] J.F. Ellena, M.A. Blazing, M.G. McNamee, Biochemistry 22 (1983) 5523-5535.

[102] A. Miyazawa, Y. Fujiyoshi, N. Unwin, Nature 423 (2003) 949-955.

[103] T. Tsukihara, K. Shimokata, Y. Katayama, H. Shimada, K. Muramoto, H. Aoyama, M. Mochizuki, K. Shinzawa-Itoh, A. Yamashita, M. Yao, Y. Ishimura, S. Yoshikawa, Proc. Natl. Acad. Sci. USA 100 (2003) 15304-15309.

[104] R.L. Cornea, L.R. Jones, J.M. Autry, D.D. Thomas, Biochemistry 36 (1997) 29602967.

[105] J. Pérez-Gil, C. Casals, D. Marsh, Biochemistry 34 (1995) 3964-3971.

[106] D. Marsh, Biochemistry (2008), submitted for publication.

[107] M.R.R. de Planque, D.V. Greathouse, R.E. Koeppe II, H. Schäfer, D. Marsh, J.A Killian, Biochemistry 37 (1998) 9333-9345.

[108] M.R.R. de Planque, J.A.W. Kruijtzer, R.M.J. Liskamp, D. Marsh, D.V. Greathouse, R.E. Koeppe II, B. De Kruijff, J.A. Killian, J. Biol. Chem. 274 (1999) 2083920846.

[109] D. Marsh, Biophys. J. 72 (1997) 2710-2718.

[110] D. Marsh, J. Mol. Biol. 297 (2000) 803-808.

[111] T. Páli, D. Marsh, Biophys. J. 80 (2001) 2789-2797.

[112] M. Ramakrishnan, J. Qu, C.L. Pocanschi, J.H. Kleinschmidt, D. Marsh, Biochemistry 44 (2005) 3515-3523.

[113] G.L. Powell, P.F. Knowles, D. Marsh, Biochim. Biophys. Acta 816 (1985) 191194.

[114] D. Marsh, Biophys. J. 93 (2007) 3884-3899.

[115] D. Marsh, Biophys. J. 94 (2008) 3996-4013.

[116] L.I. Horváth, P.J. Brophy, D. Marsh, Biochemistry 27 (1988) 46-52.

[117] L.I. Horváth, P.J. Brophy, D. Marsh, J. Magn. Reson. B105 (1994) 120-128.

[118] T. Páli, M.E. Finbow, D. Marsh, Biochemistry 38 (1999) 14311-14319.

[119] T. Páli, J.H. Kleinschmidt, G.L. Powell, D. Marsh, Biochemistry 39 (2000) 2355-2361.

[120] A. Arora, D. Marsh, Biophys. J. 75 (1998) 2915-2922.

[121] A. Arora, M. Esmann, D. Marsh, Biochemistry 38 (1999) 10084-10091.

[122] L.I. Horváth, P.J. Brophy, D. Marsh, Biophys. J. 64 (1993) 622-631.

[123] M.M.E. Snel, D. Marsh, Biophys. J. 67 (1994) 737-745.

[124] T. Páli, L.I. Horváth, D. Marsh, J. Magn. Reson. A101 (1993) 215-219.

[125] D. Marsh, Methods Enzymol. 294 (1999) 59-92.

[126] J.-H. Sachse, M.D. King, D. Marsh, J. Magn. Reson. 71 (1987) 385-404.

[127] M.D. King, J.-H. Sachse, D. Marsh, J. Magn. Reson. 72 (1987) 257-267.

[128] P. Meier, J.-H. Sachse, P.J. Brophy, D. Marsh, G. Kothe, Proc. Natl. Acad. Sci. USA 84 (1987) 3704-3708.

[129] L.I. Horváth, P.J. Brophy, D. Marsh, Biochemistry 27 (1988) 5296-5304

[130] L.I. Horváth, D. Marsh, J. Magn. Reson. 54 (1983) 363-373.

[131] L.I. Horváth, P.J. Brophy, D. Marsh, Biochim. Biophys. Acta 1147 (1993) 277280.

[132] H. Görrissen, D. Marsh, A. Rietveld, B. De Kruijff, Biochemistry 25 (1986) 2904-2910.

[133] W. Jordi, B. De Kruijff, D. Marsh, Biochemistry 28 (1989) 8998-9005. 
[134] A. Lange, D. Marsh, K.-H. Wassmer, P. Meier, G. Kothe, Biochemistry 24 (1985) 4383-4392.

[135] M. Moser, D. Marsh, P. Meier, K.-H. Wassmer, G. Kothe, Biophys. J. 55 (1989) 111-123.

[136] Y.V.S. Rama Krishna, D. Marsh, Biochim. Biophys. Acta 1024 (1990) 89-94.

[137] J.H. Kleinschmidt, J.E. Mahaney, D.D. Thomas, D. Marsh, Biophys. J. 72 (1997) 767-778.

[138] M. Ramakrishnan, V. Anbazhagan, T.V. Pratap, D. Marsh, M.J. Swamy, Biophys. J. 81 (2001) 2215-2225.

[139] M.J. Swamy, D. Marsh, V. Anbazhagan, M. Ramakrishnan, FEBS Lett. 528 (2002) 230-234.

[140] G.G. Montich, D. Marsh, Biochemistry 34 (1995) 13139-13145.

[141] G.G. Montich, C. Montecucco, E. Papini, D. Marsh, Biochemistry 34 (1995) 11561-11567.

[142] M.M.E. Snel, A.I.P.M. de Kroon, D. Marsh, Biochemistry 34 (1995) 3605-3613.

[143] R.C.A. Keller, M.M.E. Snel, B. De Kruijff, D. Marsh, FEBS Lett. 358 (1995) 251254.

[144] R.C.A. Keller, D. ten Berge, N. Nouwen, M.M.E. Snel, J. Tommassen, D. Marsh, B. De Kruijff, Biochemistry 35 (1996) 3063-3071.

[145] M.B. Sankaram, P.J. Brophy, D. Marsh, Biochemistry 28 (1989) 9685-9691.

[146] A. Rietveld, G.A.E. Ponjee, P. Schiffers, W. Jordi, P.J.F.M. Van de Coolwijk, R.A. Demel, D. Marsh, B. De Kruijff, Biochim. Biophys. Acta 818 (1985) 398-409.

[147] A. Rietveld, T.A. Berkhout, A. Roenhorst, D. Marsh, B. De Kruijff, Biochim. Biophys. Acta 858 (1986) 38-46.
[148] M.B. Sankaram, B. De Kruijff, D. Marsh, Biochim. Biophys. Acta 986 (1989) 315-320.

[149] M.B. Sankaram, P.J. Brophy, D. Marsh, Biochemistry 28 (1989) 9692-9698.

[150] M. Ramakrishnan, P.H. Jensen, D. Marsh, Biochemistry 42 (2003) 1291912926.

[151] M.J. Swamy, D. Marsh, Biochim. Biophys. Acta 1513 (2001) 122-130.

[152] J.H. Kleinschmidt, D. Marsh, Biophys. J. 73 (1997) 2546-2555.

[153] M. Ramakrishnan, P.H. Jensen, D. Marsh, Biochemistry 45 (2006) 33863395.

[154] G. D’Errico, A.M. D’Ursi, D. Marsh, Biochemistry 47 (2008) 5317-5327.

[155] I. Plasencia, F. Baumgart, D. Andreu, D. Marsh, J. Pérez-Gil, Biochim. Biophys. Acta 1778 (2008) 1274-1282.

[156] R. Bartucci, M. Pantusa, D. Marsh, L. Sportelli, Biochim. Biophys. Acta 1564 (2002) 237-242.

[157] T. Heimburg, D. Marsh, Biophys. J. 68 (1995) 536-546.

[158] T. Heimburg, B. Angerstein, D. Marsh, Biophys. J. 76 (1999) 2575-2586.

[159] J.E. Mahaney, J. Kleinschmidt, D. Marsh, D.D. Thomas, Biophys. J. 63 (1992) 1513-1522.

[160] M.J. Swamy, L.I. Horváth, P.J. Brophy, D. Marsh, Biochemistry 38 (1999) $16333-16339$.

[161] D. Marsh, F.J. Barrantes, Proc. Natl. Acad. Sci. USA 75 (1978) 4329-4333.

[162] A. Pautsch, G.E. Schulz, J. Mol. Biol. 298 (2000) 273-282.

[163] A.D. Ferguson, E. Hofmann, J.W. Coulton, K. Diederichs, W. Welte, Science 282 (1998) 2215-2220. 